\title{
Online Price Dispersion Within and Between Seven European Countries
}

\author{
J. Rupert J. Gatti and Paul Kattuman
}

September 2003

CWPE 0343

Not to be quoted without permission 


\title{
Online Price Dispersion Within and Between Seven European Countries. ${ }^{*}$
}

\author{
J. Rupert J. Gatti \\ Faculty of Economics and Politics \\ University of Cambridge \\ Paul Kattuman \\ Judge Institute of Management Studies \\ University of Cambridge
}

August 2003

\footnotetext{
* We have been fortunate to receive excellent research assistance from Alistair Jamieson in the preparation of this chapter, and from Jihong Lee, Hyunsuk Kang, Joseph Hamed, Maris Goldmanis and Kata Csrep in the data preparation phases. We have benefited enormously from discussions with Michael Baye and John Morgan, and from the contributions they have made to the broader research programme of which this is part. Financial assistance from the ESRC (Grant No, RG35586) is gratefully acknowledged. (Corresponding author: Rupert Gatti, Faculty of Economics, Austin Robinson Building, Sidwick Avenue, Cambridge, CB3 9DD. E-mail: jrjg1@ cam.ac.uk.)
} 


\begin{abstract}
This paper provides a comprehensive analysis of online price dispersion in Europe, across a broad range of product categories and countries. Using the dominant European price comparison site we collected firm specific prices, weekly, from seven European countries (Denmark, France, Italy, Netherlands, Spain, Sweden and the United Kingdom) for 31 unique products, falling into five distinct product categories (printers, PDAs, scanners, games consoles, computer games and music), over the nine month period October 2001 to June 2002. The resulting data set comprises over 17,000 individual price observations.

Using a number of alternative measures of price dispersion we find significant differences in the degree of price dispersion observed in online markets, both between countries and across product categories. We consider alternative explanations for online price dispersion and analyze their significance in explaining the observed differences.
\end{abstract}

JEL Classification No: D4, D830, L13, M3

Key Words: Price Dispersion, Internet 


\section{Introduction}

In recent years there has been a growing empirical literature documenting surprisingly large degrees of price dispersion in online markets. Initial expectations were that the introduction of the Internet, by dramatically lowering consumer search costs, would generate greater competition between firms, and result in lower prices and reduced degrees of price dispersion. However empirical evidence from online markets does not provide unambiguous support for either proposition. ${ }^{1}$

Early empirical estimates, possibly reflecting less developed online markets, showed online prices to be higher than prices in conventional markets. ${ }^{2}$ More recent work suggests that online markets, especially in association with online price listing services, may indeed be fostering increased competition, and lowering prices. ${ }^{3}$ However there is little evidence of a similar reduction in online price dispersion over the period, with observed degrees of price dispersion comparable to, or even greater than, those in conventional markets. Clay, Krishnan \& Wolff (2001), for example, observe price ranges of 38\%-65\% amongst US online book sellers, while Baye, Morgan and Scholten (2002) find average price ranges of around 40\% for a wide variety electronic appliances listed on an online price comparison site in the US.

To date the empirical evidence for online price dispersion has been obtained, almost exclusively, from the United States and concentrated in a restricted set of markets - primarily books and CDs. The intention of our study is to extend the analysis in two dimensions: comparing degrees of price dispersion between different product categories and between different national markets. The broad scope of the study allows us investigate the extent to which results obtained from US markets generalise to other national settings, and determine to what extent institutional differences that may exist between countries and product types impact on the operation and competitiveness of online markets.

\footnotetext{
${ }^{1}$ Smith, Bailey and Brynjolfsson (2000) and Kapur (2001) provide good reviews of competitive impact of online markets and (early) empirical literature.

${ }^{2}$ Lee (1997), Bailey (1998)

${ }^{3}$ Brynjolfsson and Smith (2000) find prices for a selection of books and CDs 9-16\% lower online than at conventional stores. Brown and Goolsbee (2002) have estimated similar savings for life insurance. Zettelmeyer et al. (2001) show that not all consumers benefit equally by purchasing automobiles online, but estimate an average saving of around 2\%. Ellison and Ellison (2001) estimate extremely high elasticities of demand for computer memory sold from a price listing service. See also Pan et al. (2002) for a comparison of prices charge by purely online firms with bricks-and-clicks firms.
} 
To achieve this, firm specific pricing data was downloaded for a selection of 31 products from an online price listing service in seven European countries - Denmark, France, Italy, Netherlands, Spain, Sweden and the UK. This data was downloaded from the dominant price comparison service in Europe, Kelkoo, which operates separate websites in all seven countries. Firm and product specific pricing data was downloaded from each national website, weekly, from October 2001 until June 2002 giving 17644 individual price observations. To enable a broad analysis across both product types and national boundaries the products were selected from within six broad categories of goods (Games, Games Consoles, Music, PDAs, Printers and Scanners) which all have fairly developed online markets and well defined products, allowing us to monitor identical products in all seven countries. To the best of our knowledge this is the first study of price dispersion for a varied basket of products in any one of the seven countries involved, and the first to directly compare price dispersion between countries. ${ }^{4}$

We find significant and systematic differences in the degrees of price dispersion observed between both product categories and countries, and consider a number of alternative explanations. A robust finding from the analysis is that relative price dispersion falls as the level of prices rise, so cheaper goods typically have relatively greater price dispersion than more expensive items. Consistent with theoretical predictions, we find that the impact of changes in the number of firms listing prices depends on which measure of price dispersion and which country is considered. However, having corrected for these and other determinants, we find Games Consoles, Music and Computer Games have significantly lower levels of price dispersion than the other categories, and that France and Spain have significantly lower levels of price dispersion than the other European countries studied.

The remainder of the paper proceeds as follows: in Section 2 we discuss the existing theoretical and empirical literature on price dispersion, in both conventional and online markets. Section 3 describes in detail the nature of the data we collected and Section 4 provides a descriptive summary of the results obtained. Regression results, using the two-part model to overcome mass points of zero dispersion markets, are presented in Section 5, and the conclusions are contained in Section 6.

\footnotetext{
${ }^{4}$ The timing of the data collection coincided with the introduction of the Euro for retail transaction in four of the countries involved. In an associated study (Baye, Gatti, Kattuman and Morgan, 2003) we analyse the impact of the introduction of the Euro on average and lowest prices in these countries.
} 


\section{Price Dispersion: Theory and Empirical Evidence}

There are two main theoretical approaches to modelling price dispersion for homogenous products. One approach, following Stigler's (1961) seminal paper most directly, is to assume that consumers are imperfectly informed about prices and that searching amongst firms to obtain price information is a costly activity. In these 'search' models price dispersion in equilibrium is typically obtained by introducing variations in the consumer search costs (Rob, 1985), willingness to pay (Diamond, 1987), or firm characteristics (Reinganum, 1979) although such variation is not strictly necessary (Burdett and Judd, 1983, Gatti, 2002). One consistent comparative static prediction from these models is that price dispersion falls as the cost of search falls. Stigler (1961) also conjectured that price dispersion would be relatively lower for higher priced products than lower priced products.

The second theoretical approach for modelling price dispersion, following Salop and Stiglitz (1977), Varian (1980) and Stahl (1989), is to have a proportion of consumers who have access to a complete list of posted prices and are thus perfectly 'informed' about available prices, and a proportion of 'uninformed' consumers with no access to the list of prices. The 'informed' consumers are price sensitive and purchase from the store charging the lowest price while the 'uninformed' consumers select stores at random, although their behaviour may also take the form of store loyalty rather than ignorance. This 'price posting' approach has been particularly popular when modelling price dispersion in online markets (Baye and Morgan, 2001, Brown and Goolsbee, 2002, Baye et al., 2003) where consumers possessing internet access are assumed to be able to access multiple prices costlessly, possibly through a price listing service such as Kelkoo, while consumers without online access face costly search. Interesting, and at times counter-intuitive, comparative static results may occur in these models. ${ }^{5}$

Brown and Goolsbee (2002) show that price dispersion will initially increase with increases in the number of informed consumers, but will eventually fall. Equilibria in these models depend on the maximum level of mark-up that firms can sustain over marginal costs. An increase in the mark-up, through either an increase in the

\footnotetext{
${ }^{5}$ Rosenthal shows that the mean price will rise as the number of firms in the market increase. Morgan, Orzen and Sefton (2001) derive additional comparative static results, which they confirmed experimentally.
} 
consumers' 'willingness to pay' for the product or a reduction in marginal costs, will be associated with an increase in both the mean price and price dispersion. Baye, Morgan and Scholten (2002) show that an increase in the number of firms listing prices may be associated with either an increase or a decrease in the range of distribution of prices - depending on whether or not, and how, changes in firm numbers are correlated with changes in consumer demand.

There is now a wealth of empirical evidence of price dispersion for almost homogeneous products. Stigler (1961) motivated his analysis by arguing that price dispersion is ubiquitous and citing two examples, one for Chevrolet cars in Chicago in $1959^{6}$ and the other for anthracite coal delivered in Washington DC in April 1953. Subsequently there have been a number of studies providing empirical evidence for price dispersion across a broad range of product types. The results from a selection of these studies are summarised in Table 1.

While various alternative measures of price dispersion have been applied, the two reported in Table 1, the coefficient of variation and the range, are the most frequently applied measures. The coefficient of variation, defined as the standard deviation of prices divided by the mean price, has the advantage of being both scale independent and unaffected by changes in the number of price observations sampled. The range, being the difference between highest and lowest price quotation observed, is most usually represented as a percentage or ratio of the minimum price. As such, the range measure remains scale independent but is not independent of the size of the sample taken. $^{7}$ The range measure is also particularly susceptible to distortion by outliers.

\section{INSERT TABLE 1 ABOUT HERE}

Pratt et al. (1979) and Carlson and Pescatrice (1980) provide early examples of systematic empirical studies of price dispersion across a range of product types. Pratt et al. selected 39 'standardized' products at random from the Boston Yellow Pages, ranging from the provision of a horoscope to a microwave oven. Sampling all firms listed in the Yellow Pages for the selected products they obtained price ranges that varied from $11 \%$ (for a bicycle) to $567 \%$ (for a styling brush), with an average range

\footnotetext{
${ }^{6}$ This example is drawn from Jung (1960)

${ }^{7}$ Clearly, as a purely statistical property, an increase in the number of observations taken will both raise the expected maximum price observed and lower the expected minimum observed price.
} 
of nearly $120 \%$. The coefficient of variation can be easily calculated from the summary statistics provided, and these vary from $4 \%$ to $71 \%$ with an average of $21.6 \%$.

Carlson and Pescatrice (1980) selected 34 specific products designed to cover a range of possible search behaviours, such as frequent/infrequent purchases (potatoes versus mattress) and routine/emergency purchases (deodorant versus batteries). They report coefficients of variation that vary from $3.27 \%$ (expensive camera) to $41.38 \%$ (contraceptives) with an overall average of $13.1 \%$.

More recently Sorenson (2000) collected price quotations for 152 top selling prescription drugs from 20 pharmacies in Middleton and Newburgh, NY, and reports an average coefficient of variation of $22 \%$. Aalto-Setala (2002) analyses price data for 120 grocery items obtained from 157 stores across Finland. He obtains values for the coefficient of variation between $4 \%$ and $32 \%$, with an average of $12.6 \%$.

Two robust findings emerge from these studies. Price dispersion is 'ubiquitous, even for homogenous goods' and there is wide variation between levels of price dispersion observed in different markets. All the studies cited appeal to search based models of price dispersion to motivate analysis of observed variations in price dispersion. Without exception these studies find price dispersion to be significantly lower for products expected to have lower search costs, such as frequently purchased items. Interestingly, they also consistently demonstrate a significant reduction in the coefficient of variation as the mean price of the commodity rises - but less than proportionately. That is, a $10 \%$ increase in mean price is associated with a positive, but less than $10 \%$ increase in the standard deviation of prices - causing a reduction in the overall coefficient of variation. This is usually cited as confirmation of Stigler's conjecture.

The general lesson obtained from empirical studies of price dispersion in conventional markets has been that lower search costs are associated with lower levels of price dispersion, leading to the expectation that the introduction of online markets would significantly reduce observed levels of price dispersion. Recent empirical evidence from online markets challenges this hypothesis. As Table 1(b) shows, measures of price dispersion in online markets do not appear to be significantly lower than those observed in conventional markets.

Scholten and Smith (2002) measure levels of price dispersion in both conventional and online markets in 2000 for a basket of products directly comparable with those 
selected by Carlson and Pescatrice (1980), and conclude that there is no evidence for lower price dispersion in either market since the original article. Brynjolfsson and Smith (2000) collect price information on 20 book titles and 20 CD titles from 16 firms selected to form a cross section of online and conventional stores. They find significant levels of price dispersion in online markets for both books and CDs and conclude that, in comparison with conventional stores, there is weak evidence for slightly higher levels of price dispersion in the book market and slightly lower levels of price dispersion in the CD market. Clay, Krishnan \& Wolff (2001) conduct a more extensive survey of the online book market, collecting prices for 399 book titles from 32 online book stores over a 25 week period. They find levels of price dispersion comparable with Brynjolfsson and Smith (2000), together with significant variation in price dispersion across book categories. Specifically they find books in high demand (NYT bestsellers) have the lowest average prices and the highest price dispersion while books with low demand have the highest average prices and lowest price dispersion. These results are consistent with theoretical price posting models if the number of firms listing prices is independent of, or at least only weakly correlated with, demand for the book.

Clay and Tay (2001), in the only previous study we are aware of to compare online prices internationally, monitoring the prices for 95 textbooks at nine online stores based in four countries (US, Canada, UK and Germany). They find significant differences between prices charged across countries (summarised by the price dispersion measures reported in Table 1) but the size of their sample makes it impractical to calculate price dispersion measures for each country separately.

Undoubtedly the most comprehensive study of online pricing to date is Baye, Morgan, Scholten (2002). Their study collects prices for the 1000 best selling consumer electronic products from the price listing service Shopper.com, daily, for eight months. Overall the average coefficient of variation in their study is $9.69 \%$ and the average range is approximately $40 \%$. In contrast to Clay et al. (2001) they find that both the coefficient of variation and percentage range are generally lower for the most popular products. They also analyse the impact of the number of firms quoting prices on levels of price dispersion, finding that the coefficient of variation falls as the number of firms rise while the range rises with the number of firms - at least initially. In contrast to our study Baye, Morgan and Scholten (2002) do not consider the impact 
of the price level itself on the degree of price dispersion, nor do they separate products into categories to allow inter-industry differences.

In recognition of the ambiguous impact from changes in the number of firms listing prices between the various theoretical models, Baye, Morgan and Scholten (2002) propose an alternative measure of price dispersion, which they term the 'Gap', recording the difference between the lowest and second lowest price observed. They show that the various theoretical models all predict the Gap measure of price dispersion to fall as the number of firms in the market rises, although this may not reflect any change in the equilibrium distribution of prices per se. As predicted, their analysis confirms that the Gap falls significantly with the number of firms listing prices, and with product popularity.

As is apparent from Table 1, the existing empirical evidence on price dispersion has concentrated on US markets. In this study we extend the empirical evidence on price dispersion by analysing and comparing online price dispersion for an identical basket of commodities in seven countries and between different product categories.

\section{Data Description}

The price data for this study was downloaded directly from the price listing service Kelkoo. Kelkoo is the dominant price listing service in Europe, operating within seven countries that are members of the European Union; Denmark, France, Italy, Netherlands, Spain, Sweden and the United Kingdom ${ }^{8}$. It is either the first or second most accessed price listing service in all seven countries and throughout the period of the study was accessed by over one million distinct users each month. ${ }^{9}$

Despite obvious language differences, the layout and structure of the Kelkoo web pages are very similar between countries. On each site consumers are offered a broad range of product categories which, while differing slightly between countries, typically includes music, books, computer hardware and software, electronic and household appliances, clothing, cars, telephones and telephonic services, travel services and so on. There are several alternative ways of searching for specific

\footnotetext{
${ }^{8}$ In addition to these countries Kelkoo also operates in Norway (not a member of the EU) and, since the completion of the study, has opened a site in Germany.

${ }^{9}$ Kelkoo was founded in France in 1999 and, primarily through mergers and acquisitions, rapidly expanded into other European countries over the following two years. In the two countries with the most developed Internet retail markets (France and the United Kingdom) Kelkoo is accessed by over twice as many individual users each month as its next closest rival. Within France it has the same name recognition as Amazon.com. (Statistics from Jupiter MMXI and Hitwise Statistics)
} 
products on any site - but the choice of search methods available to consumers is identical on all the national sites. Once a product has been identified Kelkoo provides a list of firms selling the desired product, together with the prices charged and some additional information such as delivery costs.

\section{INSERT FIGURE 1 NEAR HERE}

Figure 1 shows a screenshot of the prices listed for the Palm m505 PDA in the UK on 1 March 2002. Seven firms offer the product, at seven different prices ranging from $£ 281.99$ to $£ 349.99$. Consumers interested in purchasing an item 'click through' from the Kelkoo page to the firm's own web site using the 'More' button. Kelkoo's revenue is generated by charging firms a fee for each consumer 'click through' to the firm's site. The fees charged vary between product categories and countries, but range from $€ 0.30$ to $€ 1.50$ per 'click through'. Firms are not charged a fixed fee to list on Kelkoo, although there is an implicit cost to the firm of formatting data on the web site for access by Kelkoo. Firms select the national sites that they wish to be listed on, so consumers accessing a specific site view price quotations only from firms that have selected to be listed at that site. Consumers are not charged any fees to access Kelkoo.

The similarity in structure and layout of the Kelkoo sites, both internationally and amongst product categories, is an important feature of the data collected. This similarity should not only minimizes any behavioural differences that may be generated by different web page layouts but also minimizes differences in the cost of search between the different products. It is this consistency between different national and product specific web sites which allows us to meaningfully compare degrees of price dispersion between sites.

For this study we collected firm and price information from the Kelkoo sites in all seven EU countries for 31 specific and well-defined products, across six main product categories: Games, Games Consoles, Music CDs, PDAs, Printers and Scanners - a full list of the products selected appears in Table A1 in the Appendix. These categories were selected to reflect areas where online retailing was strongest and where product differentiation between countries was smallest. ${ }^{10}$ Within categories all

\footnotetext{
${ }^{10}$ As is apparent from Table A1 all products are identical at the level of product model or name, however national language differences mean products are not strictly identical. PDAs and games have language specific software differences, while other products may have language specific packaging
} 
the products selected were identified to be selling well in at least three countries at the start of the study.

For each of the 31 products selected, all firm-specific price quotations listed on each of the seven national Kelkoo websites were downloaded, weekly, for 30 weeks from October 252001 until June 6 2002. ${ }^{11}$ This resulted in 17644 individual price observations across 4699 country/product/date specific websites. Summary statistics, including mean and minimum prices together with the various measures of price dispersion, were calculated for each of the country/product/date specific websites to form the dataset used in the present study.

All the prices used in this study include sales tax, exclude transportation and delivery charges, and have been converted into Euros at the relevant daily rate. Including delivery charges into the analysis has no significant impact on the results reported, being typically small relative to the observed price variation.

\section{Summary Statistics}

Table 2 presents summary statistics for three commonly used measures of price dispersion; coefficient of variation, range and Gap, all in percentages. As price dispersion is only meaningful when two or more firms are quoting prices, in this table we have excluded those (900) records for which only one firm listed a price-leaving 3799 records with two or more price quotations ${ }^{12}$.

\section{INSERT TABLE 2 NEAR HERE}

Table 2 shows that price dispersion is a prevalent feature of online markets. Overall, across all countries and products, the average coefficient of variation is $10.1 \%$, the average range is $28 \%$ and the average gap is $10.9 \%$ - figures broadly in line with those of previous studies. However these general averages disguise considerable variation across both countries and product categories, with the

\footnotetext{
differences. Books, for example, were ignored in this study as they suffer particularly from language specificity.

${ }^{11}$ Specifically, the program GoZilla! was used to download the relevant pages from the various Kelkoo sites. These files were converted from html code into a format suitable for econometric analysis by a specialist software company in India, Cordiant Interweb Technologies.

${ }^{12}$ The averages have been calculated giving equal weighting to each relevant record - so, for example, the overall average for a specific country takes the average of all records from that country, rather than taking an average of the category or product averages within the country. Clearly, as not all products have multiple price quotations in all countries at all times, these two methods differ.
} 
coefficient of variation varying from $2.2 \%$ for Consoles in Spain to $20.4 \%$ for Games in the Netherlands, the range varying from 3.8\% for Consoles in Spain to $73.1 \%$ for Games in the Denmark, and the Gap varying from 1.6\% for Consoles in France to $34.6 \%$ for Games in the Netherlands.

Despite the variability, consistent patterns of relative dispersion measures across categories and countries are discernable from Table 2 . The average price dispersion for Games is at least twice as large as the average price dispersion for Consoles whichever measure of price dispersion we consider and, looking more closely, the same is true within five of the seven individual countries. The relative rankings of products and categories, shown in Table 2, are remarkably consistent for each measure of price dispersion. Consoles and PDAs are ordered lowest and second lowest respectively in all measures, while Music and Games are consistently ranked second highest and highest. On the face of it these results are surprising, Music and Games are the two categories where one may expect consumers to make a greater proportion of multiple purchases - and thus may be expected to have the lowest degrees of price dispersion. Regression results in the following section show that this apparent anomaly can be fully explained by the fact that these are also the cheapest products in the study.

Comparing countries we see that Sweden, Denmark and the Netherlands are ranked highest in all measures of price dispersion while France and Italy are always ranked within the lowest three countries.

Tables A2(a)-(h), in the Appendix, provide a more detailed breakdown of the principle summary statistics, calculated at the product /country level, together with the standard deviations of these values across the collection dates. The first two columns of each sub-table show the mean number of firms listing prices and the mean price listed for each commodity in the specified country, averaged over all periods the product was listed. The subsequent columns give the mean and standard deviation for the three measures of price dispersion considered, where empty cells denote products that were never listed by more than one firm in the specific country. Once again the variation in observed levels of price dispersion are large - not only between products and across countries, but also for the same product in the same country over time. The standard deviations for the measures of price dispersion are comparable to, and frequently larger than, the mean values themselves - suggesting skewed distributions since prices are bounded below. 
There are of course a number of explanations for the variation in price dispersion displayed in Table 2 and Table A2 other than country and product specific differences in industrial structure. Table $3 \mathrm{a}$ shows the average number of firms listing prices at each site, by country and category. Clearly considerable differences exist. On average there are over twice as many firms listing prices in France (5.6) than in the Netherlands (2.5), while in (almost) every country there are more firms listing prices for both Music and PDAs than for either Scanners or Consoles ${ }^{13}$.

\section{INSERT TABLE 3 NEAR HERE:}

The numbers of firms listing prices, in all countries, are significantly lower than comparable statistics collected in the US. Baye, Morgan and Scholten (2002) find an average of 17.3 firms listing prices, across more than 1000 commodities. This difference reflects, amongst other things, the relative size, level of development and sophistication of online markets in the US and Europe. Further evidence of the relative development of online markets between countries is apparent form Table $3 \mathrm{~b}$, showing the frequency of the number of firms listing prices, by country. The countries with the highest mode number of firms, France(5), the UK (5) and Sweden (4), are the three European countries with the most developed online markets. In comparison the other four countries have modes of either 1 or 2 firms listing prices, with numbers tailing off quite rapidly above 3 firms.

\section{INSERT FIGURE 2 NEAR HERE}

Figure 2 shows how the three measures of price dispersion vary with the number of firms listing prices, averaged across all categories and countries. The Gap measure of price dispersion falls consistently from nearly $17 \%$ when only two firms are listing prices down to $4 \%$ when 10 firms are listing. This contrasts with the behaviour of the other two measures, which rise with the number of firms. The range measure doubling from $20 \%$ to $40 \%$ as the number of firms rise from 2 to 9 , and the coefficient of variation rising slightly over the same interval. Both the range and the coefficient of variation measures decrease substantially when more than 9 firms list prices, but this

\footnotetext{
${ }^{13}$ The one exception to this in the UK where, on average, more firms listed Consoles than PDAs.
} 
may reflect both a small sample set and selection bias - Table $3 \mathrm{~b}$ shows that the overwhelming majority of the records involving 10 or more firms originate in France. $^{14}$

The results displayed in Figure 2 show some remarkable consistencies with the results obtained by Baye, Morgan and Scholten (2002) for the US markets, and one notable inconsistency. While, as noted above, there are considerably fewer firms listing prices in out data set than there were in the US study, over the same domain Baye, Morgan and Scholten show a fall in the Gap measure from $23 \%$ to $4 \%$ as the number of firms listing rises from 2 to 10 , and a rise in the range from $23 \%$ to $40 \%{ }^{15}$ Although they do not report the direct relationship between the coefficient of variation and the number of firms, their regression results provide evidence for precisely the opposite effect than observed here, with the coefficient of variation decreasing as the number of firms rises. We discuss this discrepancy in more detail in Section 5

\section{INSERT FIGURES 3\&4 SOMEWHERE HERE}

Figure 3 shows how the average levels for the three measures of price dispersion drift upwards, in a consistent manner, over the course of the study. Given the contrasting impact of changes in the number of firms on the coefficient of variation/range measures and the Gap measure, this is unlikely to have been due to changes in the number of firms. Figure 4 shows that in fact the average number of firms listing prices fell over the period, further compounding the explanation for the increased coefficient of variation and range measures.

\section{INSERT FIGURES 5-7 SOMEWHERE HERE}

Finally, we consider the impact of variation in average prices on the various measures of price dispersion. Figures 5-7 plot price dispersion against mean or minimum price for all 3799 observations. Despite all three measures being, theoretically, scale independent these plots all suggest a negative correlation between price dispersion and average price. It is possible, however, that this apparent negative correlation is just a repercussion of the relatively high price dispersion observed in the

\footnotetext{
${ }^{14} \mathrm{It}$ is for this reason that the results in Figure 2 have been aggregated for 10 firms and over.

${ }^{15}$ Baye, Morgan and Scholten (2002), Figures 6\&7.
} 
cheapest two categories, Games and Music, so some care is required in interpreting these Figures.

The summary statistics suggest that there is considerable variation in the observed degrees of price dispersion between both countries and categories, and there are a number of possible explanations for these - including differences in the number of firms listing prices, differences in the value of the product as well as potentially important industry specific and country specific differences in market structure. In order to obtain a clearer understanding of the relevance and relative importance of these alternative explanations more detailed econometric analysis is required, which is conducted in the next section.

\section{Regression Analysis}

Measures of price dispersion are continuous over their positive range, but potentially have a mass of observations at zero - thus they are limited dependent variables. This is a potential econometric issue which, to our knowledge, has not been sufficiently noted in the price dispersion literature.

Of the 4669 country/product/time specific observations made over the nine month period, 900 had only a single firm listing prices and were therefore incapable of exhibiting price dispersion. Of the 3799 remaining observations, where price dispersion in principle could have been observed, the coefficient of variation and the range measures of price dispersion took zero values in 129 (3.4\%) cases, while the gap measure was zero in $707(19 \%)$ cases. By far the majority of these cases fell in France and Spain, in terms of countries; and in games and game consoles, in terms of categories.

There are many statistical approaches to the modeling of limited dependent variables. A straightforward method is the two-part model (2PM), which comprises of a probit or logit model for the probability that there is any dispersion at all in the price distribution, and an OLS, applied to the sub-sample with non-zero dispersion, to estimate determinants of the positive level of dispersion. Application of OLS to only part of the sample introduces the possibility of sample selection bias. The consistency of the 2PM for the model parameters rests on the assumption that, conditional on dispersion being positive, its unobservable determinants together giving rise to the error term has zero mean. This can be justified if the factors that make for positive 
dispersion have no relationship to the factors that actually determine the degree of dispersion. For example, it may be that a market with no price dispersion cannot be explained simply in terms of the absence (or reduction) of factors that increase the level of dispersion. In other words, causes that drive the positive level of dispersion (such as the price level) may not be related to factors that tip a market between no dispersion and positive dispersion. However, correlation between unobservables would still arise where common variables are omitted from the two stages of the dispersion driving process.

In contrast to the two independent processes assumed by 2PM, the Tobit model assumes a single process, an assumption which may appear strong. The motivation may be set out in terms of competition in markets being determined simultaneously by utility maximizing (search) behaviour of consumers, and the behaviour of firms. This model can be described using the concept of a latent, equilibrium level of dispersion, with zero dispersion representing corner solutions where, either due to excessive search or due to extreme competition between firms, all firms charge the same price. Positive dispersion corresponds to observed equilibria. The Tobit model can be estimated by maximum likelihood and these estimates are approximated by the OLS estimates from the $2 \mathrm{PM}$ divided by the proportion of non-zero observations in the sample.

The sample selection model (SSM) lies between the above two extremes and allows for two interdependent decisions. The process generating positive dispersion and the process determining the amount of dispersion can be influenced by distinct but correlated observable and unobservable factors. While the SSM is, in an informal sense, more general, it makes greater demands on the data from the point of view of identification. It is advantageous, but not always easy, to find a variable that influences whether there will be any dispersion, but conditional on this, does not influence the positive level of dispersion. The Tobit and 2PM circumvent this problem by assumption.

There cannot be an a priori case for the use of any one model over another. In choosing between the Tobit model, the 2PM and the SSM, we need to consider the strength of assumptions that are made, the likely degree of selection bias and the information available for identification. In this study we report the 2PM estimates.

In Table 4 we report the marginal effects on the probability of positive dispersion obtained from the Probit model, for each of the three measures of price dispersion. 
Dummy variables are included to account for differences in countries, categories, time (in months) and the number of firms, with the omitted variables being France, Consoles, October 2001 and '2 firms' respectively.

\section{INSERT TABLE 4 NEAR HERE}

For both the coefficient of variation and the range the probability of positive dispersion increases significantly when the number of firms goes from 2 to 3 , but thereafter no further significant number of firm effects are observed. PDAs, printers and scanners have significantly higher probability of positive dispersion than games consoles, games and music while, as reported earlier, zero measures of price dispersion are most likely in France and Italy. The price level has no significant effect on the probability of positive dispersion with either of these measures.

The results are different in the case of the gap measure - the probability of positive dispersion generally declines with the number of firms, and an increase in the price level leads to a significant decrease in the probability of a positive gap measure. As with the other measures of dispersion, PDAs, printers and scanners have significantly higher probability of positive dispersion than games consoles, games and music. But in the gap measure there are no significant differences between countries.

In Table 5 we report estimates from the OLS regression, applied only to the subsample of observations with non-zero dispersion. Since all the measures of dispersions showed positive skew, $\log$ transformations of the dispersion variables was appropriate for this model, and allow intuitive interpretation of the results. The relatively small proportion of zero valued observations, and the large sample size, suggest that applying OLS to only positive part of the sample should not cause serious concerns about sample selection bias.

Table 5 shows regression results for each of the three measures of price dispersion. Once again the omitted dummy variables in these regressions are France, Consoles, October 2001 and '2 firms' listing prices, so the results are with reference to these. It is important to note that, in addition to taking log transformation, the range and Gap measures have been taken as ratios rather than being expressed in percentage terms, which makes a difference to the interpretation of the coefficients in Table 5.

\section{INSERT TABLE 5 NEAR HERE}


All three measures of price dispersion show highly significant, and negative, price level effects. Having allowed for product category dummies, which may be expected to pick up industry specific differences between, say, cheaper CDs and the more expensive electronic items, the elasticity of the coefficient of variation with respect to mean price is -0.48 . The elasticity of range ratio with respect minimum price is -0.21 , and that of the gap ratio, -0.13 . All these coefficients are also significantly greater than -1 , thus in all cases increases in the denominator of each of the dependent variables is associated with increases in the numerator, but a less than proportional increase. Thus products with higher price levels have higher standard deviations, but lower coefficients of variation.

We find a strong positive relationship between the number of firms listing and both the coefficient of variation and the range measures, and a negative relationship between the number of firms and the Gap. Increasing the number of firms listing prices from 2 to 8 or more raises the coefficient of variation by over $30 \%$, the range ratio by over $17 \%$ and decreases the Gap ratio by around $6 \%$. Represented in term of percentages, rather than ratios, these figures correspond to an increase in the coefficient of variation from $10 \%$ to $13 \%$, a rise in the range from $20 \%$ to $42 \%$ and a fall in the Gap from $20 \%$ to $13 \%$, very much in line with the results displayed in Figure 2.

Controlling for all else, we find that Music, Games and Games Consoles have significantly lower levels of price dispersion than the other categories of goods, no matter which measure of price dispersion is used. The higher absolute levels of price dispersion observed in the Games and Music sectors are thus fully explained, primarily by the price effect. In fact, confirming search theoretic predictions, dispersion is relatively lower in these sectors. The surprising result here is that Games Consoles have unusually low measures of price dispersion.

Between countries, Italy, the Netherlands and Sweden consistently have significantly higher levels of price dispersion than France, while price dispersion in Spain is not significantly different from France under any measure.

To test for the robustness of these general results we ran similar country and category specific regressions. With all but one exception, the results were consistent with all of the results identified above. The exception was the impact of the number of firms on the coefficient of variation. 


\section{INSERT TABLE 6 NEAR HERE}

Table 6 shows the results of country specific regressions on the coefficient of variation. As observed earlier, the impact of mean price on the coefficient of variation is negative in all countries, and highly significant everywhere except Italy. A positive impact of number of firms on the coefficient of variation is observed in four countries, but in Italy and Spain there is no significant relationship between the two, and in France there is a significant negative affect. As was noted earlier, Baye, Morgan and Scholten (2002) also observe a negative relationship between the number of firms and the coefficient of variation in their analysis of US markets. Given the theoretical ambiguity on the predicted impact of changes in the number of firms on price dispersion, highlighted in Section 2, these apparently inconsistent empirical findings are perhaps more revealing than matters of concern.

\section{Conclusion}

In this descriptive study we have analysed price dispersion within, and between, seven European countries for a variety of directly comparable products. Considerable variation in the levels of price dispersion between countries, products, and over time are apparent.

One robust finding from our analysis is that price dispersion is relatively lower for higher valued products than cheaper products. We show that, ignoring this relationship can lead to misleading comparisons of price dispersion and market structure across product categories.

Comparing product categories, we find the lowest degrees of price dispersion for Games and Music sectors and, more surprisingly, for Games Consoles as opposed to the other categories. Significant cross country differences in price dispersion are also observed, with France and Spain having the lowest degrees of price dispersion and Italy, the Netherlands and Sweden the highest.

The impact on price dispersion of the numbers of firms listing prices for a product is shown to be ambiguous, depending not only on which measure of price dispersion is adopted but also which countries are considered - a result itself consistent with the theoretical literature. 
In addition to providing detailed information on, and insight into, the determinants of price dispersion in online markets within Europe in this study we also highlight the need to take separate account of the mass of observations where price dispersion is zero. This is will be an important consideration for the growing number of studies of online markets where many thousands of separate observations may be recorded. 


\section{Bibliography}

Aalto-Setala, V. (2002) 'Explaining Price Dispersion for Homogeneous Grocery Products'. Mimeo.

Bailey, J.P. (1998) Intermediation and Electronic Markets: Aggregation and Pricing in Internet Commerce. Ph.D., Technology, Management and Policy, MIT.

Baye, M.R., Gatti, J.R.J, Kattuman, P. and Morgan, J. (2003) 'Online Pricing and the Euro Changeover: Cross-Country Comparisons'. Mimeo.

Baye, M.R. and Morgan, J. (2001) 'Information Gatekeepers on the Internet and the Competitiveness of Homogeneous Product Markets'. American Economic Review 91, 454--474.

Baye, M.R., Morgan, J. and Scholten, P. (2002) 'Price Dispersion in the Small and in the Large: Evidence from an Internet Price Comparison Site'. Mimeo.

Brown, J.R. and Goolsbee, A. (2002) 'Does the Internet Make Markets More Competitive? Evidence from the Life Insurance Industry'. Journal of Political Economy 110(3), 481--507.

Brynjolfsson, E. and Smith, M.D. (2000) 'Frictionless Commerce? A comparison of Internet and Conventional Retailers'. Management Science 46(4), 563--585.

Burdett, K. and Judd, K.L. (1983) 'Equilibrium Price Dispersion'. Econometrica 51(4), 955--970.

Carlson, J.A. and Pescatrice, D.R. (1980) 'Persistent Price Distributions'. Journal of Economics and Business 33(1), 21--27.

Clay, K., Krishnan, R. and Wolff, E. (2001) 'Prices and Price Dispersion on the Web: Evidence from the Online Book Industry'. NBER Working Paper No. w8271.

Clay,K. and Tay, C.H. (2001) 'Cross-Country Price Differentials in the Online Textbook Market'. Working Paper, Carnegie Mellon University,

Clemon, E.K., Hann, I-H. and Hitt, L.M. (2000) 'The Nature of Competition in Electronic Markets: An Empirical Investigation of Online Travel Agent Offerings'. Working paper, Wharton School, University of Pennsylvania. 
Daripa, A. and Kapur, S. (2001) 'Pricing on the Internet'. Oxford Review of Economic Policy 17(2), 202--216.

Diamond, P.A. (1987) 'Consumer Differences and Prices in a Search Model'. Quarterly Journal of Economics 102(2), 429--436.

Ellison, G. and Ellison, S.F. (2001) 'Search, Obfuscation, and Price Elasticities on the Internet'. Mimeo.

Gatti, J.R.J. (2002) 'Equilibrium Price Dispersion with Sequential Search'. Mimeo, Cambridge University.

Jung, A.F. (1960) 'Price Variations Among Automobile Dealers in Metropolitan Chicago'. Journal of Business 33(1), 31--42.

Lee, H.G. (1997) 'Do Electronic Marketplaces Lower the Price of Goods'. Communications of the ACM 41(12).

Morgan, J., Orzen, H. and Sefton, M. (2001) 'An Experimental Study of Price Dispersion'. Mimeo. 
Pan, X., Shankar, V. and Ratchford, B.T. (2002) 'Price Competition Between Pure Play versus Bricks-and-Clicks e-Tailers: Analytical Model and Empirical Analysis', in: Baye, M.R. (Ed.), Advances in Applied Microeconomics, Vol. 11, 29--61.

Pratt, J.W., Wise, D.A. and Zeckhauser, R. (1979) 'Price differences in almost competitive markets'. The Quarterly Journal of Economics 93(2), 189--211.

Reinganum, J.F. (1979) 'A Simple Model of Equilibrium Price Dispersion'. Journal of Political Economy 87, 851--858.

Rob, R. (1985) 'Equilibrium Price Dispersions'. Review of Economic Studies 52(3), 487--504.

Rosenthal, R.W. (1980) 'A Model in Which an Increase in the Number of Sellers Leads to a Higher Price'. Econometrica 48(6), 1575--1580.

Salop, S. and Stiglitz, J. (1977) 'Bargains and Ripoffs: A Model of Monopolistically Competitive Price Dispersion'. Review of Economic Studies 44(3), 493--510.

Scholten, P. and Smith, S.A. (2002) 'Price Dispersion Then and Now: Evidence from Retail and E-tail Markets', in Baye, M.R. (Ed.), Advances in Applied Microeconomics, Vol. 11, pp 63--88.

Sorensen, A.T. (2000) 'Equilibrium Price Dispersion in Retail Markets for Prescription Drugs'. Journal of Political Economy 108(4), 833--850.

Smith, M.D., Bailey, J. and Brynjolfsson, E. (2000) 'Understanding Digital Markets: Review and Assessment', in: Brynjofsson, E. and Kahin, B., (Eds.), Understanding the Digital Economy, 2000, pp. 99--136.

Stahl, D.O. (1989) 'Oligopolistic Pricing with Sequential Consumer Search'. American Economic Review 79(4), 700--712.

Stigler, G.J. (1961) 'The Economics of Information'. Journal of Political Economy 69(3), 213--225.

Varian, H. (1980) ‘A Model of Sales’. American Economic Review 70(4), 651--659.

Zettelmeyer, F., Scott Morton, F.M. and Silva-Risso, J. (2001) 'Cowboys or Cowards: Why are Internet Car Prices Lower?' NBER Working Paper No. w8667. 
Appendix

INSERT TABLE A1 HERE

INSERT TABLE A2 HERE 
Table 1: Summary of Price Dispersion Literature

a) Conventional Markets

\begin{tabular}{|c|c|c|c|c|c|}
\hline Study & Product Type & Region & Data Source & $\begin{array}{c}\text { Coeff. of } \\
\text { Variation }\end{array}$ & Range \\
\hline $\begin{array}{c}\text { Stigler (1961) [from } \\
\text { Jung (1960)] }\end{array}$ & Automobiles & Chicago & Individual Dealers & $1.7 \%$ & $7.0 \%$ \\
\hline Stigler (1961) & Coal & Washington DC & $\begin{array}{l}\text { Bids for govt. } \\
\text { purchases }\end{array}$ & $6.8 \%$ & $22.4 \%$ \\
\hline $\begin{array}{c}\text { Pratt, Wise and } \\
\text { Zeckhauser (1979) }\end{array}$ & Varied & Boston & Individual Stores & $21.6 \% *$ & $119.5 \% *$ \\
\hline $\begin{array}{c}\text { Carlson and } \\
\text { Pescatrice (1980) }\end{array}$ & Varied & New Orleans & Individual Stores & $13.1 \%$ & - \\
\hline Sorensen (2000) & Prescription drugs & $\begin{array}{l}\text { Upstate New } \\
\text { York }\end{array}$ & Individual Stores & $22.0 \%$ & - \\
\hline $\begin{array}{c}\text { Scholten and Smith } \\
(2002)\end{array}$ & Varied & Indiana & Individual Stores & $18.2 \%$ & - \\
\hline Aalto-Setala (2002) & Groceries & Finland & Individual Stores & $12.6 \%$ & - \\
\hline
\end{tabular}

b) Online Markets

\begin{tabular}{|c|c|c|c|c|c}
\hline Study & Product Type & Region & Data Source & $\begin{array}{c}\text { Coeff. of } \\
\text { Variation }\end{array}$ & Range \\
\hline $\begin{array}{c}\text { Clemon, Hann \& } \\
\text { Hitt (2000) }\end{array}$ & Airline Tickets & US & Online Travel Agents & - & $18 \%$ \\
\hline $\begin{array}{c}\text { Brynjolfsson \& } \\
\text { Smith (2000) }\end{array}$ & Books & US & 8 online stores & - & $33 \%$ \\
\hline $\begin{array}{c}\text { Clay and Tay } \\
(2001)\end{array}$ & Books & $\begin{array}{c}\text { US, Canada, UK } \\
\text { and Germany }\end{array}$ & 9 online bookstores & $23.5-33.7 \% *$ & - \\
\hline $\begin{array}{c}\text { Clay, Krishnan \& } \\
\text { Wolff (2001) }\end{array}$ & Books & US & 32 online bookstores & $\begin{array}{c}12.9-27.7 \% * \\
{[2]}\end{array}$ & $38.6-$ \\
\hline $\begin{array}{c}\text { Baye,Morgan \& } \\
\text { Scholten (2002) }\end{array}$ & Electronics & US & Shopper.com & $9.7 \%$ & $\sim 40 \%$ \\
\hline $\begin{array}{c}\text { Scholten \& Smith } \\
(2002)\end{array}$ & Varied & US & mySimon.com & $14.5 \%$ & - \\
\hline $\begin{array}{c}\text { Ellison \& Ellison } \\
(2001)\end{array}$ & Computer Memory & US & Pricewatch.com & - & $\sim 4 \%[4]$ \\
\hline
\end{tabular}

[*] Own calculations from Summary Data

[1] Figures vary across book category.

[2] Figures vary across class of book: [New York Times bestsellers: 27.7\%; Former NYT bestsellers: 17.8\%; Computer bestsellers: 15.6\%; Former computer bestsellers: 14.0\%; Random books: 12.9\%]

[3] As a percentage of mean (not minimum) price and, therefore, an underestimate relative to the other figures Figures vary across class of book. [New York Times bestsellers: 65.2\%; Former NYT bestsellers: 42.8\%; Computer bestsellers: 38.6\%; Former computer bestsellers: 35.7\%; Random books: $31.9 \%$ ]

[4] Uses Range of 10 lowest price offers, while the full range is of hundreds, and so is not directly comparable 
Table 2: Price Dispersion by Country and Category

a) Coefficient of Variation (\%)

\begin{tabular}{|c|c|c|c|c|c|c|c||c||c||}
\hline & France & Italy & Netherlands & Spain & Sweden & UK & Denmark & $\begin{array}{c}\text { Category } \\
\text { Average }\end{array}$ & Rank \\
\hline Consoles & 3.0 & 13.8 & 5.6 & 2.2 & 8.4 & 3.5 & 9.7 & 6.1 & 1 \\
\hline Games & 9.8 & 6.2 & 20.4 & 9.6 & 13.6 & 12.8 & 20.2 & 13.9 & 6 \\
\hline CDs & 15.3 & 8.8 & 12.3 & 13.3 & 14.0 & 16.2 & 8.7 & 12.8 & 5 \\
\hline PDAs & 8.3 & 4.3 & 7.4 & 7.2 & 6.6 & 5.2 & 7.9 & 6.7 & 2 \\
\hline Printers & 7.3 & 8.9 & 11.3 & 8.6 & 7.1 & 9.4 & 9.4 & 8.7 & 3 \\
\hline Scanners & 12.4 & 14.2 & 10.1 & 6.0 & 8.0 & 3.9 & 6.3 & 8.9 & 4 \\
\hline \hline $\begin{array}{c}\text { Country } \\
\text { Average }\end{array}$ & 9.5 & 8.5 & 12.6 & 8.7 & 10.4 & 10.0 & 11.6 & 10.1 & \\
\hline \hline Rank & 3 & 1 & 7 & 2 & 5 & 4 & 6 & & \\
\hline
\end{tabular}

b) Range (\%)

\begin{tabular}{|c|c|c|c|c|c|c|c||c||c|}
\hline & France & Italy & Netherlands & Spain & Sweden & UK & Denmark & $\begin{array}{c}\text { Category } \\
\text { Average }\end{array}$ & Rank \\
\hline Consoles & 7.8 & 27.7 & 8.9 & 3.8 & 17.3 & 8.7 & 18.9 & 12.8 & 1 \\
\hline Games & 29.5 & 9.3 & 54.6 & 19.1 & 50.4 & 36.8 & 73.1 & 42.9 & 6 \\
\hline CDs & 47.4 & 25.0 & 40.6 & 32.4 & 40.4 & 54.9 & 17.1 & 37.5 & 5 \\
\hline PDAs & 27.9 & 10.0 & 15.9 & 16.3 & 16.4 & 11.7 & 20.2 & 17.1 & 2 \\
\hline Printers & 21.0 & 21.3 & 24.8 & 21.6 & 18.9 & 23.1 & 23.9 & 22.0 & 4 \\
\hline Scanners & 29.4 & 27.8 & 17.3 & 10.8 & 19.1 & 7.0 & 12.6 & 19.2 & 3 \\
\hline \hline $\begin{array}{c}\text { Country } \\
\text { Average }\end{array}$ & 28.3 & 20.1 & 33.4 & 19.9 & 31.3 & 28.9 & 33.1 & 28.0 & \\
\hline \hline Rank & 3 & 2 & 7 & 1 & 5 & 4 & 6 & & \\
\hline
\end{tabular}

c) Gap (\%)

\begin{tabular}{|c|c|c|c|c|c|c|c||c||c|}
\hline & France & Italy & Netherlands & Spain & Sweden & UK & Denmark & $\begin{array}{c}\text { Category } \\
\text { Average }\end{array}$ & Rank \\
\hline Consoles & 1.6 & 13.7 & 8.9 & 3.7 & 9.1 & 2.5 & 10.1 & 6.1 & 1 \\
\hline Games & 10.0 & 9.1 & 34.6 & 15.2 & 15.6 & 14.5 & 31.9 & 19.0 & 6 \\
\hline CDs & 9.6 & 9.4 & 14.9 & 18.0 & 13.2 & 9.1 & 10.3 & 12.0 & 5 \\
\hline PDAs & 8.7 & 3.6 & 10.5 & 5.6 & 6.4 & 3.9 & 5.9 & 6.2 & 2 \\
\hline Printers & 4.2 & 10.8 & 12.8 & 9.9 & 5.9 & 6.8 & 3.6 & 7.5 & 3 \\
\hline Scanners & 16.1 & 23.5 & 16.0 & 7.7 & 6.4 & 6.7 & 6.4 & 11.1 & 4 \\
\hline \hline $\begin{array}{l}\text { Country } \\
\text { Average }\end{array}$ & 8.1 & 9.3 & 18.0 & 11.2 & 10.5 & 8.2 & 13.4 & 10.9 & \\
\hline \hline Rank & 1 & 3 & 7 & 5 & 4 & 2 & 6 & & \\
\hline
\end{tabular}


Table 3: Number of Firms Listing Prices

a) Mean Number of Firms by Country and Category

\begin{tabular}{|c|c|c|c|c|c|c|c||c|}
\hline & France & Italy & Netherlands & Spain & Sweden & UK & Denmark & Average \\
\hline Consoles & 4.5 & 2.3 & 1.3 & 2.2 & 2.6 & 4.2 & 1.8 & 2.9 \\
\hline Games & 6.2 & 1.1 & 1.9 & 2.3 & 4.7 & 4.1 & 4.1 & 3.7 \\
\hline CDs & 5.0 & 4.6 & 4.1 & 3.3 & 4.6 & 6.8 & 2.4 & 4.4 \\
\hline PDAs & 7.5 & 4.2 & 2.4 & 2.9 & 4.7 & 3.7 & 4.0 & 4.2 \\
\hline Printers & 6.2 & 3.1 & 2.6 & 3.9 & 3.8 & 3.9 & 3.8 & 4.0 \\
\hline Scanners & 2.9 & 1.8 & 1.6 & 1.7 & 3.8 & 2.0 & 1.6 & 2.4 \\
\hline \hline Average & 5.6 & 3.2 & 2.5 & 2.9 & 4.2 & 4.4 & 3.1 & 3.8 \\
\hline
\end{tabular}

b) Frequency Table: Number of Firms by Country

\begin{tabular}{|c|c|c|c|c|c|c|c||c|}
\hline No. of firms & France & Italy & Netherlands & Spain & Sweden & UK & Denmark & Total \\
\hline $\mathbf{1}$ & 64 & 164 & 215 & 130 & 87 & 75 & 165 & 900 \\
\hline $\mathbf{2}$ & 39 & 95 & 158 & 221 & 80 & 80 & 173 & 846 \\
\hline $\mathbf{3}$ & 66 & 90 & 104 & 131 & 89 & 93 & 114 & 687 \\
\hline $\mathbf{4}$ & 103 & 71 & 56 & 99 & 146 & 114 & 80 & 669 \\
\hline $\mathbf{5}$ & 156 & 92 & 33 & 57 & 110 & 121 & 60 & 629 \\
\hline $\mathbf{6}$ & 112 & 36 & 35 & 25 & 54 & 88 & 49 & 399 \\
\hline $\mathbf{7}$ & 55 & 12 & 16 & 12 & 34 & 64 & 24 & 217 \\
\hline $\mathbf{8}$ & 52 & 5 & 1 & 11 & 33 & 39 & 12 & 153 \\
\hline $\mathbf{9}$ & 37 & 7 & 0 & 1 & 19 & 14 & 6 & 84 \\
\hline $\mathbf{1 0}$ & 29 & 4 & 0 & 0 & 17 & 3 & 6 & 59 \\
\hline $\mathbf{1 1}$ & 19 & 1 & 0 & 0 & 1 & 2 & 2 & 25 \\
\hline $\mathbf{1 2}$ & 10 & 0 & 0 & 0 & 0 & 0 & 1 & 11 \\
\hline $\mathbf{1 3}$ & 7 & 0 & 0 & 0 & 0 & 0 & 0 & 7 \\
\hline $\mathbf{1 4}$ & 6 & 0 & 0 & 0 & 0 & 0 & 0 & 6 \\
\hline $\mathbf{1 5}$ & 7 & 0 & 0 & 0 & 0 & 0 & 0 & 7 \\
\hline \hline Total & 762 & 577 & 618 & 687 & 670 & 693 & 692 & 4699 \\
\hline
\end{tabular}


$\underline{\text { Table 4: Probit Model for positive price dispersion }}$

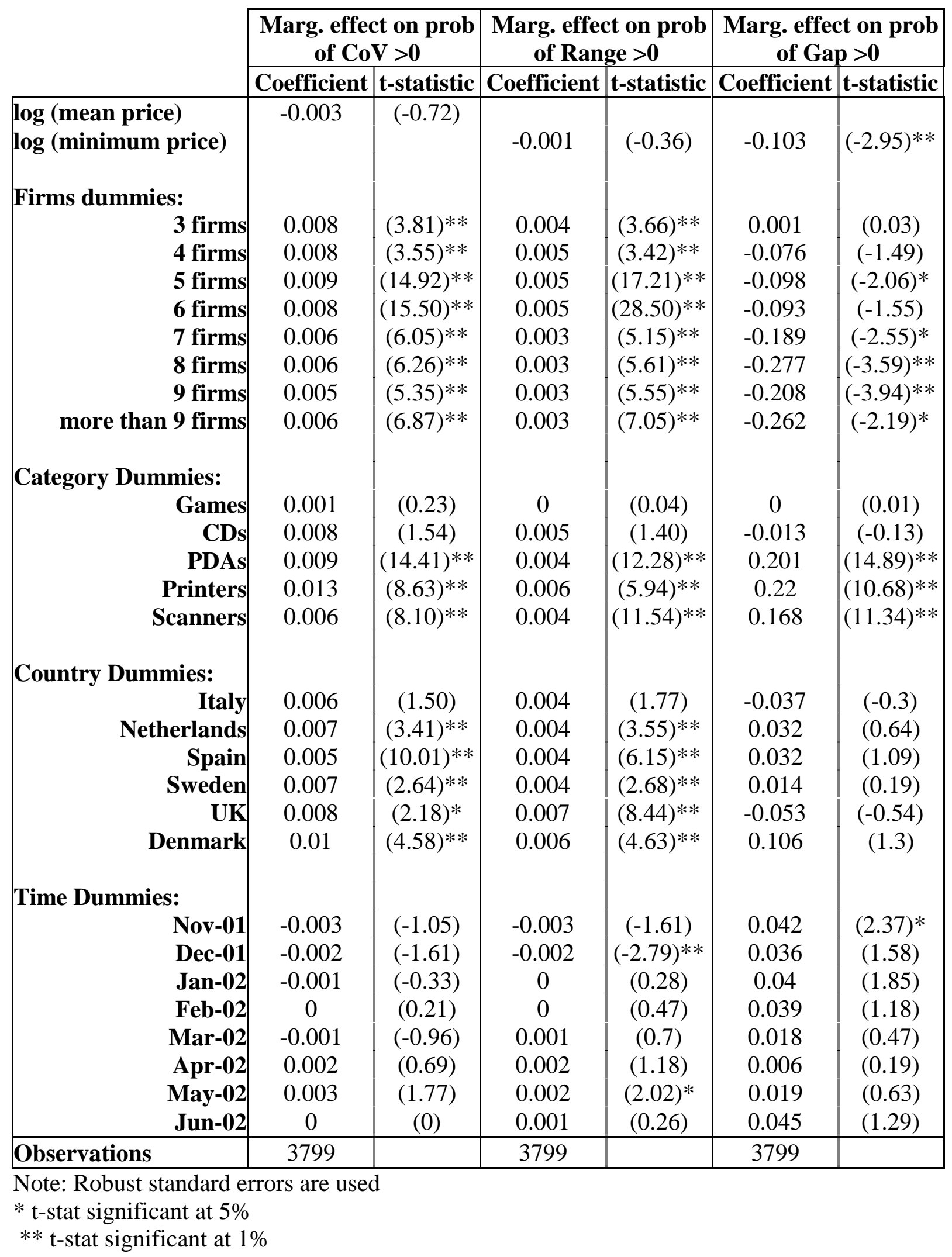


Table 5: OLS Regressions on Price Dispersion

\begin{tabular}{|c|c|c|c|c|c|c|}
\hline \multirow{3}{*}{\begin{tabular}{|l|} 
Dependent Variable \\
\end{tabular}} & \multicolumn{2}{|c|}{ Model 1} & \multicolumn{2}{|c|}{ Model 2} & \multicolumn{2}{|c|}{ Model 3} \\
\hline & \multicolumn{2}{|c|}{$\log$ (Coeff. of Variation) } & \multicolumn{2}{|c|}{ log( Range ) } & \multicolumn{2}{|c|}{$\log ($ Gap ) } \\
\hline & Coefficient & t-statistic & Coefficient & t-statistic & Coefficient & t-statistic \\
\hline $\log ($ mean price) & -0.48 & $(-10.32)^{* *}$ & & & & \\
\hline $\log$ (minimum price) & & & -0.213 & $(-19.31)^{* *}$ & -0.13 & $(-15.04)^{* *}$ \\
\hline \multicolumn{7}{|l|}{ Firms dummies: } \\
\hline 3 firms & 0.017 & $(0.28)$ & 0.065 & $(7.04)^{* *}$ & -0.032 & $(-4.01)^{* *}$ \\
\hline 4 firms & 0.182 & $(3.51)^{* *}$ & 0.087 & $(9.03)^{* * *}$ & -0.045 & $(-5.55)^{* *}$ \\
\hline 5 firms & 0.196 & $(3.67)^{* *}$ & 0.114 & $(12.12)^{* *}$ & -0.063 & $(-8.23) * *$ \\
\hline 6 firms & 0.265 & $(4.85)^{* *}$ & 0.137 & $(13.42)^{* *}$ & -0.063 & $(-7.71)^{* *}$ \\
\hline 7 firms & 0.249 & $(3.88)^{* *}$ & 0.15 & $(9.93)^{* *}$ & -0.057 & $(-5.04) * *$ \\
\hline 8 firms & 0.329 & $(4.84)^{* *}$ & 0.172 & $(9.95)^{* *}$ & -0.063 & $(-5.49) * *$ \\
\hline 9 firms & 0.399 & $(4.85)^{* *}$ & 0.177 & $(8.25)^{* *}$ & -0.079 & $(-6.16)^{* *}$ \\
\hline more than 9 firms & 0.32 & $(4.76)^{* *}$ & 0.172 & $(11.51)^{* *}$ & -0.045 & $(-3.99) * *$ \\
\hline \multicolumn{7}{|l|}{ Category Dummies: } \\
\hline Games & 0.303 & $(2.58)^{* *}$ & -0.202 & $(-10.62)^{* *}$ & -0.11 & $(-7.65)^{* * *}$ \\
\hline CDs & 0.014 & $(0.10)$ & -0.421 & $(-13.65)^{* *}$ & -0.287 & $(-12.66)^{* *}$ \\
\hline PDAs & 0.798 & $(8.40)^{* *}$ & 0.1 & $(8.31)^{* *}$ & 0.063 & $(6.44)^{* *}$ \\
\hline Printers & 1.216 & $(11.74)^{* *}$ & 0.223 & $(14.99)^{* *}$ & 0.119 & $(9.67)^{* *}$ \\
\hline Scanners & 0.964 & $(9.02) * *$ & 0.107 & $(7.41)^{* *}$ & 0.057 & $(4.90)^{* *}$ \\
\hline \multicolumn{7}{|l|}{ Country Dummies: } \\
\hline Italy & 0.242 & $(4.04)^{* *}$ & 0.027 & $(2.50)^{*}$ & 0.031 & $(3.80)^{* *}$ \\
\hline Netherlands & 0.172 & $(2.38)^{*}$ & 0.087 & $(6.29)^{* *}$ & 0.054 & $(4.76)^{* *}$ \\
\hline Spain & 0.087 & $(1.49)$ & 0.017 & $(1.66)$ & 0.008 & $(1.04)$ \\
\hline Sweden & 0.237 & $(4.96)^{* *}$ & 0.041 & $(3.79)^{* *}$ & 0.019 & $(2.34)^{*}$ \\
\hline UK & 0.059 & $(1.18)$ & 0.03 & $(2.98)^{* *}$ & 0.001 & $(0.10)$ \\
\hline Denmark & 0.345 & $(6.60)^{* *}$ & 0.069 & $(5.58)^{* * *}$ & 0.014 & (1.72) \\
\hline \multicolumn{7}{|l|}{ Time Dummies: } \\
\hline Nov-01 & -0.009 & $(-0.11)$ & 0.005 & $(0.36)$ & 0.015 & $(1.78)$ \\
\hline Dec-01 & 0.042 & $(0.51)$ & 0.007 & $(0.48)$ & 0.022 & $(2.41)^{*}$ \\
\hline Jan-02 & 0.088 & (1.06) & 0.015 & (1.07) & 0.03 & $(3.05)^{* *}$ \\
\hline Feb-02 & 0.016 & $(0.19)$ & 0.004 & $(0.26)$ & 0.023 & $(2.42)^{*}$ \\
\hline Mar-02 & 0.165 & (1.96) & 0.027 & $(1.82)$ & 0.042 & $(3.91)^{* *}$ \\
\hline Apr-02 & 0.25 & $(2.74)^{* *}$ & 0.045 & $(2.73)^{* * *}$ & 0.054 & $(4.38)^{* *}$ \\
\hline May-02 & 0.228 & $(2.65)^{* *}$ & 0.065 & $(4.28)^{* * *}$ & 0.052 & $(4.92)^{* *}$ \\
\hline Jun-02 & 0.061 & $(0.54)$ & 0.028 & (1.33) & 0.035 & $(2.15)^{*}$ \\
\hline Constant & 3.347 & $(12.13)^{* *}$ & 1.146 & $(19.94)^{* *}$ & 0.758 & $(16.74)^{* *}$ \\
\hline Observations & 3653 & & 3653 & & 3092 & \\
\hline R-Squared & 0.2 & & 0.37 & & 0.28 & \\
\hline
\end{tabular}

Note: Robust standard errors are used

* t-stat significant at 5\%

** $\mathrm{t}$-stat significant at $1 \%$ 
Table 6: OLS Regressions on Coefficient of Variation within National Markets

\begin{tabular}{|c|c|c|c|c|c|c|c|}
\hline & \begin{tabular}{|c|} 
Model 1 \\
France
\end{tabular} & \begin{tabular}{|c|} 
Model 2 \\
Italy
\end{tabular} & \begin{tabular}{|c|} 
Model 3 \\
Netherlands \\
\end{tabular} & $\begin{array}{c}\text { Model } 4 \\
\text { Spain } \\
\end{array}$ & $\begin{array}{l}\text { Model } 5 \\
\text { Sweden } \\
\end{array}$ & \begin{tabular}{|c|} 
Model 6 \\
UK
\end{tabular} & $\begin{array}{r}\text { Model } 7 \\
\text { Denmark }\end{array}$ \\
\hline Dependent Variable & $\log \mathrm{CoV}$ & $\log \mathrm{CoV}$ & $\log \mathrm{CoV}$ & $\log \mathrm{CoV}$ & $\log \mathrm{CoV}$ & $\log \mathrm{CoV}$ & $\log \mathrm{CoV}$ \\
\hline log (mean price) & $\begin{array}{c}-0.345 \\
(-4.12)^{* *}\end{array}$ & $\begin{array}{l}-0.165 \\
(-1.23)\end{array}$ & $\begin{array}{c}-0.984 \\
(-3.82)^{* *}\end{array}$ & $\begin{array}{c}-0.75 \\
(-4.70)^{* *}\end{array}$ & $\begin{array}{c}-0.364 \\
(-3.84)^{* *}\end{array}$ & $\begin{array}{c}-0.768 \\
(-6.84)^{* *}\end{array}$ & $\begin{array}{c}-0.768 \\
(-6.84)^{* *}\end{array}$ \\
\hline \begin{tabular}{|} 
Firms dummies: \\
3 firms
\end{tabular} & $\begin{array}{c}-0.502 \\
(-2.34)^{*}\end{array}$ & $\begin{array}{l}-0.203 \\
(-1.40)\end{array}$ & $\begin{array}{l}-0.246 \\
(-1.43)\end{array}$ & $\begin{array}{l}-0.008 \\
(-0.07)\end{array}$ & $\begin{array}{l}0.032 \\
(0.24)\end{array}$ & $\begin{array}{l}0.234 \\
(1.43)\end{array}$ & $\begin{array}{l}0.234 \\
(1.43)\end{array}$ \\
\hline 4 firms & $\begin{array}{c}-0.57 \\
(-3.32) * *\end{array}$ & $\begin{array}{l}0.044 \\
(0.34)\end{array}$ & $\begin{array}{l}0.149 \\
(0.87)\end{array}$ & $\begin{array}{l}0.155 \\
(1.62)\end{array}$ & $\begin{array}{l}0.041 \\
(0.34)\end{array}$ & $\begin{array}{l}0.323 \\
(2.42)^{*}\end{array}$ & $\begin{array}{c}0.323 \\
(2.42)^{*}\end{array}$ \\
\hline 5 firms & $\left|\begin{array}{c}-0.517 \\
(-2.66) * *\end{array}\right|$ & $\begin{array}{l}-0.153 \\
(-1.27)\end{array}$ & $\begin{array}{l}0.086 \\
(0.51)\end{array}$ & $\begin{array}{c}0.328 \\
(3.01)^{* *}\end{array}$ & $\begin{array}{l}0.151 \\
(1.15)\end{array}$ & $\begin{array}{c}0.397 \\
(3.01)^{* *}\end{array}$ & $\begin{array}{c}0.397 \\
(3.01)^{* *}\end{array}$ \\
\hline 6 firms & $\begin{array}{c}-0.422 \\
(-2.39)^{*}\end{array}$ & $\begin{array}{l}-0.137 \\
(-1.06)\end{array}$ & $\begin{array}{c}0.32 \\
(1.91)\end{array}$ & $\begin{array}{c}0.396 \\
(2.87)^{* *}\end{array}$ & $\begin{array}{l}0.161 \\
(1.22)\end{array}$ & $\begin{array}{c}0.526 \\
(3.95)^{* *}\end{array}$ & $\begin{array}{c}0.526 \\
(3.95) * *\end{array}$ \\
\hline 7 firms & $\begin{array}{c}-0.735 \\
(-3.80) * *\end{array}$ & $\begin{array}{l}-0.008 \\
(-0.04)\end{array}$ & $\begin{array}{c}0.33 \\
(1.47)\end{array}$ & $\begin{array}{c}0.51 \\
(3.42)^{* *}\end{array}$ & $\begin{array}{c}0.489 \\
(3.34)^{* *}\end{array}$ & $\begin{array}{c}0.373 \\
(2.82)^{* *}\end{array}$ & $\begin{array}{c}0.373 \\
(2.82)^{* *}\end{array}$ \\
\hline 8 firms & $\begin{array}{c}-0.597 \\
(-3.21)^{* *}\end{array}$ & $\begin{array}{l}-0.462 \\
(-1.88)\end{array}$ & $\begin{array}{l}-0.047 \\
(-0.22)\end{array}$ & $\begin{array}{c}0.713 \\
(4.16) * *\end{array}$ & $\begin{array}{c}0.533 \\
(3.53)^{* *}\end{array}$ & $\begin{array}{c}0.54 \\
(3.63)^{* *}\end{array}$ & $\begin{array}{c}0.54 \\
(3.63)^{* *}\end{array}$ \\
\hline 9 firms & $\begin{array}{l}-0.269 \\
(-1.19)\end{array}$ & $\begin{array}{l}0.047 \\
(0.29)\end{array}$ & $\begin{array}{l}- \\
-\end{array}$ & $\begin{array}{c}1.252 \\
(8.52) * *\end{array}$ & $\begin{array}{c}0.389 \\
(2.20)^{*}\end{array}$ & $\begin{array}{c}0.514 \\
(3.62) * *\end{array}$ & $\begin{array}{c}0.514 \\
(3.62)^{* *}\end{array}$ \\
\hline more than 9 firms & $\begin{array}{c}-0.51 \\
(-3.04) * *\end{array}$ & $\begin{array}{l}0.086 \\
(0.46)\end{array}$ & $\begin{array}{l}- \\
-\end{array}$ & $\begin{array}{l}- \\
-\end{array}$ & $\begin{array}{c}0.436 \\
(2.87)^{* *}\end{array}$ & $\begin{array}{c}0.426 \\
(2.30)^{*}\end{array}$ & $\begin{array}{c}0.426 \\
(2.30)^{*}\end{array}$ \\
\hline $\begin{array}{l}\text { Category Dummies: } \\
\text { Country Dummies: } \\
\text { Time Dummies: }\end{array}$ & $\begin{array}{l}\text { Yes } \\
\text { Yes } \\
\text { Yes }\end{array}$ & $\begin{array}{l}\text { Yes } \\
\text { Yes } \\
\text { Yes }\end{array}$ & $\begin{array}{l}\text { Yes } \\
\text { Yes } \\
\text { Yes }\end{array}$ & $\begin{array}{l}\text { Yes } \\
\text { Yes } \\
\text { Yes }\end{array}$ & $\begin{array}{l}\text { Yes } \\
\text { Yes } \\
\text { Yes }\end{array}$ & $\begin{array}{l}\text { Yes } \\
\text { Yes } \\
\text { Yes }\end{array}$ & $\begin{array}{l}\text { Yes } \\
\text { Yes } \\
\text { Yes }\end{array}$ \\
\hline Constant & $\begin{array}{c}2.649 \\
(5.25)^{* *}\end{array}$ & $\begin{array}{c}3.432 \\
(5.01)^{* *}\end{array}$ & $\begin{array}{c}5.485 \\
(3.87)^{* *}\end{array}$ & $\begin{array}{c}2.746 \\
(2.83) * *\end{array}$ & $\begin{array}{c}4.072 \\
(7.38)^{* *}\end{array}$ & $\begin{array}{c}4.329 \\
(6.62)^{* *}\end{array}$ & $\begin{array}{c}4.329 \\
(6.62) * *\end{array}$ \\
\hline \begin{tabular}{|l|} 
Observations \\
R-Squared
\end{tabular} & $\begin{array}{l}652 \\
0.4\end{array}$ & $\begin{array}{l}400 \\
0.26\end{array}$ & $\begin{array}{l}391 \\
0.27\end{array}$ & $\begin{array}{l}504 \\
0.49\end{array}$ & $\begin{array}{l}572 \\
0.31\end{array}$ & $\begin{array}{l}610 \\
0.53\end{array}$ & $\begin{array}{r}610 \\
0.53\end{array}$ \\
\hline
\end{tabular}

Note: Robust standard errors are used

* t-stat significant at 5\%

** t-stat significant at $1 \%$ 


\section{Appendix Table A1: Products List}

\section{Product Code Product Name}

\section{Games Consoles}

Games

Music CDs

PDAs

Printers

Scanners
11 Sony Playstation 2

12 Nintendo Gameboy Advance

13 Sega Dreamcast

14 X-Box

15 Nintendo Gamecube

Super Mario Advance (Gameboy Advance) FIFA 2001 (PC)

Black \& White (PC)

Pokemon Gold (Gameboy Color)

Gran Turismo 3 (Playstation 2)

26 FIFA 2002 (PC)

31 Gorillaz (Gorillaz)

$32 \quad$ No Angel (Dido)

33 Hot Shot (Shaggy)

$34 \quad$ Hybrid Theory (Linkin Park)

35 All That You Can't Leave Behind (U2)

$41 \quad$ Palm Vx

$42 \quad$ Palm 505

43 Compaq iPaq H3630

$44 \quad$ Handspring Visor Deluxe

45 HP Jordana 720

$51 \quad$ Epson Stylus Color 1160

52 Epson Stylus Photo 1290

53 Canon S600

$54 \quad$ Canon $\mathrm{S} 800$

$55 \quad$ HP Deskjet 840

61 Epson 1640SU Photo

62 Canon CanoScan N656U

63 HP ScanJet 5370C

64 Epson Expression 1600 Pro

65 HP ScanJet 5300C 


\section{Appendix Table A2}

\begin{tabular}{|c|c|c|c|c|c|c|c|c|}
\hline \multicolumn{9}{|c|}{ a) France } \\
\hline \multirow[t]{2}{*}{ Product } & \multirow{2}{*}{$\begin{array}{l}\text { Mean no. } \\
\text { of firms }\end{array}$} & \multirow{2}{*}{$\begin{array}{l}\text { Mean } \\
\text { Price }\end{array}$} & \multicolumn{2}{|c|}{ Coeff. of Variation } & \multicolumn{2}{|c|}{ Range Ratio } & \multicolumn{2}{|c|}{ Gap Ratio } \\
\hline & & & Mean & S.D. & Mean & S.D. & Mean & S.D. \\
\hline 11 & 5.3 & 306.64 & 2.7 & 6.59 & 1.1 & 0.22 & 1.0 & 0.00 \\
\hline 12 & 5.5 & 109.90 & 3.2 & 3.74 & 1.1 & 0.10 & 1.0 & 0.02 \\
\hline 13 & 3.0 & 140.97 & 1.3 & 3.62 & 1.0 & 0.11 & 1.0 & 0.11 \\
\hline 14 & 4.3 & 403.75 & 7.1 & 11.96 & 1.2 & 0.28 & 1.1 & 0.17 \\
\hline 15 & 2.8 & 199.01 & 0.0 & 0.02 & 1.0 & 0.00 & 1.0 & 0.00 \\
\hline Consoles Avg. & 4.5 & 210.42 & 3.0 & 6.27 & 1.1 & 0.17 & 1.0 & 0.08 \\
\hline & & & & & & & & \\
\hline 21 & 6.9 & 45.46 & 1.4 & 1.99 & 1.0 & 0.07 & 1.0 & 0.05 \\
\hline 22 & 3.1 & 52.66 & 12.5 & 16.38 & 1.4 & 0.58 & 1.3 & 0.53 \\
\hline 23 & 6.3 & 51.11 & 12.6 & 9.62 & 1.4 & 0.45 & 1.2 & 0.30 \\
\hline 24 & 7.3 & 43.49 & 3.9 & 0.41 & 1.1 & 0.01 & 1.0 & 0.01 \\
\hline 25 & 6.7 & 49.75 & 22.2 & 22.31 & 1.6 & 0.60 & 1.0 & 0.04 \\
\hline 26 & 7.3 & 49.97 & 5.5 & 0.92 & 1.2 & 0.03 & 1.0 & 0.00 \\
\hline Games Avg. & 6.2 & 48.62 & 9.8 & 14.04 & 1.3 & 0.44 & 1.1 & 0.26 \\
\hline 31 & 4.8 & 18.08 & 9.7 & 3.35 & 1.3 & 0.11 & 1.1 & 0.08 \\
\hline 32 & 5.4 & 16.19 & 24.1 & 8.43 & 1.8 & 0.35 & 1.2 & 0.18 \\
\hline 33 & 5.3 & 18.90 & 16.0 & 3.84 & 1.5 & 0.16 & 1.2 & 0.10 \\
\hline 34 & 4.4 & 16.55 & 11.0 & 2.99 & 1.3 & 0.08 & 1.0 & 0.03 \\
\hline 35 & 5.2 & 17.94 & 15.9 & 2.62 & 1.4 & 0.09 & 1.0 & 0.04 \\
\hline CDs Avg. & 5.0 & 17.54 & 15.3 & 6.89 & 1.5 & 0.28 & 1.1 & 0.12 \\
\hline 41 & 5.1 & 358.35 & 12.7 & 9.01 & 1.4 & 0.39 & 1.1 & 0.12 \\
\hline 42 & 11.9 & 506.55 & 5.3 & 1.94 & 1.2 & 0.11 & 1.1 & 0.09 \\
\hline 43 & 8.1 & 219.44 & 8.5 & 1.23 & 1.3 & 0.07 & 1.1 & 0.03 \\
\hline 44 & 7.2 & 403.73 & 5.4 & 2.67 & 1.2 & 0.14 & 1.1 & 0.09 \\
\hline 45 & 3.9 & 129.24 & 11.1 & 4.37 & 1.3 & 0.15 & 1.1 & 0.12 \\
\hline PDAs Avg. & 7.5 & 342.44 & 8.3 & 5.66 & 1.3 & 0.23 & 1.1 & 0.10 \\
\hline 51 & 5.5 & 380.59 & 8.9 & 4.83 & 1.3 & 0.20 & 1.1 & 0.11 \\
\hline 52 & 10.5 & 527.52 & 6.7 & 2.33 & 1.2 & 0.10 & 1.0 & 0.01 \\
\hline 53 & 6.3 & 590.28 & 6.2 & 0.81 & 1.2 & 0.05 & 1.0 & 0.04 \\
\hline 54 & 4.0 & 236.50 & 4.2 & 1.18 & 1.1 & 0.06 & 1.1 & 0.03 \\
\hline 55 & 4.4 & 1033.45 & 9.7 & 5.06 & 1.3 & 0.16 & 1.0 & 0.02 \\
\hline Printers Avg. & 6.2 & 556.86 & 7.3 & 3.90 & 1.2 & 0.14 & 1.0 & 0.06 \\
\hline 61 & 2.5 & 397.57 & 10.1 & 6.04 & 1.2 & 0.10 & 1.1 & 0.13 \\
\hline 62 & 4.5 & 95.33 & 11.7 & 4.61 & 1.3 & 0.16 & 1.1 & 0.09 \\
\hline 63 & 2.5 & 267.88 & 4.0 & 6.55 & 1.1 & 0.16 & 1.1 & 0.14 \\
\hline 64 & 1.4 & 1090.49 & 9.9 & 0.00 & 1.2 & 0.00 & 1.2 & 0.00 \\
\hline 65 & 2.5 & 179.81 & 30.5 & 13.48 & 1.8 & 0.21 & 1.5 & 0.34 \\
\hline Scanners Avg. & 2.9 & 351.71 & 12.4 & 9.58 & 1.3 & 0.23 & 1.2 & 0.21 \\
\hline $\begin{array}{c}\text { Overall } \\
\text { Averages }\end{array}$ & 5.6 & 245.80 & 9.5 & 9.41 & 1.3 & 0.30 & 1.1 & 0.16 \\
\hline
\end{tabular}




\section{Appendix Table A2 (contd)}

\begin{tabular}{|c|c|c|c|c|c|c|c|c|}
\hline \multicolumn{9}{|c|}{ b) Italy } \\
\hline \multirow{2}{*}{ Product } & \multirow{2}{*}{$\begin{array}{c}\text { Mean no. } \\
\text { of firms }\end{array}$} & \multirow{2}{*}{$\begin{array}{l}\text { Mean } \\
\text { Price }\end{array}$} & \multicolumn{2}{|c|}{ Coeff. of Variation } & \multicolumn{2}{|c|}{ Range Ratio } & \multicolumn{2}{|c|}{ Gap Ratio } \\
\hline & & & Mean & S.D. & Mean & S.D. & Mean & S.D. \\
\hline 11 & 3.3 & 338.34 & 13.6 & 8.11 & 1.3 & 0.21 & 1.1 & 0.10 \\
\hline 12 & 1.9 & 131.28 & 12.3 & 7.32 & 1.2 & 0.13 & 1.2 & 0.14 \\
\hline 13 & 1.5 & 187.13 & 24.4 & 1.87 & 1.4 & 0.00 & 1.4 & 0.13 \\
\hline 14 & 2.6 & 414.23 & 12.4 & 14.24 & 1.3 & 0.30 & 1.1 & 0.22 \\
\hline 15 & 1.8 & 219.47 & 2.3 & 0.06 & 1.0 & 0.01 & 1.0 & 0.01 \\
\hline Consoles Avg. & 2.3 & 245.48 & 13.8 & 9.18 & 1.3 & 0.20 & 1.1 & 0.17 \\
\hline 21 & 1.3 & 52.95 & 6.5 & 1.74 & 1.1 & 0.03 & 1.1 & 0.03 \\
\hline 22 & 1.0 & 48.04 & & & & & & \\
\hline 23 & 1.0 & 51.13 & & & & & & \\
\hline 24 & 1.0 & 44.53 & & & & & & \\
\hline 25 & 1.2 & 53.84 & 5.7 & 3.63 & 1.1 & 0.05 & 1.1 & 0.06 \\
\hline 26 & 1.0 & 54.15 & & & & & & \\
\hline Games Avg. & 1.1 & 51.61 & 6.2 & 2.38 & 1.1 & 0.04 & 1.1 & 0.04 \\
\hline 31 & 4.3 & 17.94 & 6.8 & 1.41 & 1.2 & 0.04 & 1.1 & 0.03 \\
\hline 32 & 4.7 & 17.35 & 8.5 & 1.67 & 1.2 & 0.06 & 1.1 & 0.04 \\
\hline 33 & 4.6 & 18.11 & 8.5 & 1.27 & 1.2 & 0.04 & 1.0 & 0.04 \\
\hline 34 & 4.2 & 16.57 & 9.8 & 5.99 & 1.3 & 0.19 & 1.1 & 0.14 \\
\hline 35 & 5.5 & 18.67 & 9.9 & 4.73 & 1.3 & 0.23 & 1.2 & 0.20 \\
\hline CDs Avg. & 4.6 & 17.65 & 8.8 & 3.85 & 1.2 & 0.15 & 1.1 & 0.12 \\
\hline 41 & 4.0 & 379.90 & 5.1 & 1.31 & 1.1 & 0.03 & 1.0 & 0.04 \\
\hline 42 & 6.1 & 482.58 & 4.3 & 0.48 & 1.1 & 0.02 & 1.0 & 0.03 \\
\hline 43 & 3.9 & 228.62 & 4.9 & 2.76 & 1.1 & 0.05 & 1.0 & 0.03 \\
\hline 44 & 4.0 & 426.29 & 4.0 & 1.63 & 1.1 & 0.06 & 1.0 & 0.05 \\
\hline 45 & 1.6 & 102.22 & 1.4 & 4.08 & 1.0 & 0.06 & 1.0 & 0.06 \\
\hline PDAs Avg. & 4.2 & 348.55 & 4.3 & 2.16 & 1.1 & 0.05 & 1.0 & 0.04 \\
\hline 51 & 2.3 & 304.13 & 22.9 & 11.29 & 1.6 & 0.30 & 1.4 & 0.24 \\
\hline 52 & 4.7 & 528.03 & 3.6 & 2.35 & 1.1 & 0.07 & 1.0 & 0.01 \\
\hline 53 & 2.7 & 662.49 & 7.5 & 5.38 & 1.2 & 0.14 & 1.1 & 0.09 \\
\hline 54 & 1.3 & 237.71 & 5.1 & 0.00 & 1.1 & 0.00 & 1.1 & 0.00 \\
\hline 55 & 3.5 & 976.61 & 8.0 & 3.51 & 1.2 & 0.08 & 1.1 & 0.07 \\
\hline Printers Avg. & 3.1 & 589.09 & 8.9 & 8.52 & 1.2 & 0.22 & 1.1 & 0.16 \\
\hline 61 & 2.6 & 361.54 & 14.7 & 2.21 & 1.3 & 0.04 & 1.2 & 0.03 \\
\hline 62 & 1.5 & 104.35 & 8.3 & 1.21 & 1.2 & 0.06 & 1.1 & 0.03 \\
\hline 63 & 1.6 & 287.72 & 15.8 & 2.07 & 1.3 & 0.02 & 1.3 & 0.02 \\
\hline 64 & & & & & & & & \\
\hline 65 & 1.0 & 201.42 & & & & & & \\
\hline Scanners Avg. & 1.8 & 240.79 & 14.2 & 3.12 & 1.3 & 0.05 & 1.2 & 0.06 \\
\hline $\begin{array}{c}\text { Overall } \\
\text { Averages }\end{array}$ & 3.2 & 268.51 & 8.5 & 6.81 & 1.2 & 0.17 & 1.1 & 0.13 \\
\hline
\end{tabular}




\section{Appendix Table A2 (contd)}

\begin{tabular}{|c|c|c|c|c|c|c|c|c|}
\hline \multicolumn{9}{|c|}{ c) Netherlands } \\
\hline \multirow{2}{*}{ Product } & \multirow{2}{*}{$\begin{array}{c}\text { Mean no. } \\
\text { of firms }\end{array}$} & \multirow{2}{*}{$\begin{array}{l}\text { Mean } \\
\text { Price }\end{array}$} & \multicolumn{2}{|c|}{ Coeff. of Variation } & \multicolumn{2}{|c|}{ Range Ratio } & \multicolumn{2}{|c|}{ Gap Ratio } \\
\hline & & & Mean & S.D. & Mean & S.D. & Mean & S.D. \\
\hline 11 & 1.4 & 324.82 & 7.7 & 8.71 & 1.1 & 0.14 & 1.1 & 0.15 \\
\hline 12 & 1.1 & 120.41 & 2.1 & 0.00 & 1.0 & 0.00 & 1.0 & 0.00 \\
\hline \multicolumn{9}{|l|}{13} \\
\hline \multicolumn{9}{|l|}{14} \\
\hline 15 & 1.4 & 219.20 & 0.3 & 0.00 & 1.0 & 0.00 & 1.0 & 0.00 \\
\hline Consoles Avg. & 1.3 & 226.02 & 5.6 & 7.65 & 1.1 & 0.13 & 1.1 & 0.13 \\
\hline 21 & 1.5 & 46.64 & 6.1 & 16.55 & 1.1 & 0.38 & 1.1 & 0.38 \\
\hline 22 & 1.5 & 31.14 & 25.0 & 22.75 & 1.6 & 0.54 & 1.1 & 0.37 \\
\hline 23 & 1.7 & 41.02 & 34.3 & 22.79 & 1.8 & 0.58 & 1.4 & 0.53 \\
\hline 24 & 2.4 & 44.10 & 15.2 & 23.50 & 1.7 & 1.26 & 1.3 & 0.47 \\
\hline 25 & 2.3 & 62.88 & 18.5 & 25.43 & 1.4 & 0.60 & 1.4 & 0.60 \\
\hline 26 & 1.7 & 55.99 & 27.5 & 25.21 & 1.6 & 0.56 & 1.6 & 0.57 \\
\hline Games Avg. & 1.9 & 46.89 & 20.4 & 24.24 & 1.5 & 0.79 & 1.3 & 0.52 \\
\hline 31 & 4.1 & 17.02 & 9.0 & 4.99 & 1.3 & 0.28 & 1.1 & 0.19 \\
\hline 32 & 4.8 & 17.45 & 16.1 & 6.29 & 1.6 & 0.40 & 1.2 & 0.18 \\
\hline 33 & 4.3 & 18.11 & 14.9 & 4.86 & 1.5 & 0.31 & 1.2 & 0.19 \\
\hline 34 & 2.7 & 17.07 & 9.7 & 9.61 & 1.3 & 0.51 & 1.2 & 0.36 \\
\hline 35 & 4.3 & 19.41 & 11.8 & 4.82 & 1.4 & 0.28 & 1.1 & 0.20 \\
\hline CDs Avg. & 4.1 & 17.82 & 12.3 & 6.81 & 1.4 & 0.38 & 1.1 & 0.23 \\
\hline 41 & 2.9 & 360.95 & 9.5 & 3.06 & 1.2 & 0.07 & 1.1 & 0.04 \\
\hline 42 & 2.9 & 492.09 & 7.6 & 4.45 & 1.2 & 0.19 & 1.1 & 0.14 \\
\hline 43 & 2.3 & 277.03 & 6.1 & 1.19 & 1.1 & 0.04 & 1.1 & 0.04 \\
\hline 44 & 1.7 & 438.62 & 2.8 & 1.61 & 1.1 & 0.03 & 1.0 & 0.03 \\
\hline 45 & 1.0 & 95.77 & & & & & & \\
\hline PDAs Avg. & 2.4 & 390.50 & 7.4 & 3.87 & 1.2 & 0.13 & 1.1 & 0.09 \\
\hline & & & & & & & & \\
\hline$\frac{51}{52}$ & $\frac{1.6}{4.9}$ & $\begin{array}{l}473.84 \\
527.62\end{array}$ & $\frac{16.1}{110}$ & $\frac{14.07}{3.32}$ & $\frac{1.3}{1.3}$ & $\frac{0.33}{0.14}$ & $\frac{1.3}{1.0}$ & $\frac{0.32}{0.11}$ \\
\hline 53 & $\frac{4.9}{2.0}$ & 608.64 & 13.9 & 6.04 & 1.5 & 0.14 & 1.2 & 0.12 \\
\hline 54 & 1.5 & 295.60 & 11.2 & 9.06 & 1.2 & 0.16 & 1.1 & 0.18 \\
\hline 55 & 2.3 & 1027.50 & 5.9 & 6.37 & 1.1 & 0.10 & 1.1 & 0.11 \\
\hline Printers Avg. & 2.6 & 605.11 & 11.3 & 8.00 & 1.2 & 0.19 & 1.1 & 0.18 \\
\hline & & & & & & & & \\
\hline 61 & 1.8 & 380.20 & 12.4 & 2.13 & 1.2 & 0.03 & 1.2 & 0.03 \\
\hline 62 & 1.5 & 129.54 & 3.3 & 4.87 & 1.0 & 0.07 & 1.1 & 0.07 \\
\hline 63 & 1.7 & 268.09 & 11.6 & 10.82 & 1.2 & 0.21 & 1.2 & 0.21 \\
\hline 64 & & & & & & & & \\
\hline 65 & 1.4 & 288.23 & 5.9 & 2.47 & 1.1 & 0.03 & 1.1 & 0.07 \\
\hline Scanners Avg. & 1.6 & 277.90 & 10.1 & 8.24 & 1.2 & 0.16 & 1.2 & 0.16 \\
\hline $\begin{array}{c}\text { Overall } \\
\text { Averages }\end{array}$ & 2.5 & 239.78 & 12.6 & 13.75 & 1.3 & 0.47 & 1.2 & 0.31 \\
\hline
\end{tabular}


Appendix Table A2 (contd)

\begin{tabular}{|c|c|c|c|c|c|c|c|c|}
\hline \multicolumn{9}{|c|}{ d) Spain } \\
\hline \multirow[t]{2}{*}{$\overline{\text { Product }}$} & \multirow{2}{*}{$\begin{array}{c}\text { Mean no. } \\
\text { of firms }\end{array}$} & \multirow{2}{*}{$\begin{array}{l}\text { Mean } \\
\text { Price }\end{array}$} & \multicolumn{2}{|c|}{ Coeff. of Variation } & \multicolumn{2}{|c|}{ Range Ratio } & \multicolumn{2}{|c|}{ Gap Ratio } \\
\hline & & & Mean & S.D. & Mean & S.D. & Mean & S.D. \\
\hline 11 & 2.3 & 299.95 & 0.0 & 0.04 & 1.0 & 0.00 & 1.0 & 0.00 \\
\hline 12 & 2.1 & 115.22 & 4.4 & 5.74 & 1.1 & 0.09 & 1.1 & 0.09 \\
\hline 13 & 1.5 & 120.16 & 0.0 & 0.00 & 1.0 & 0.00 & 1.0 & 0.00 \\
\hline 14 & 2.3 & 359.62 & 5.1 & 11.06 & 1.1 & 0.27 & 1.1 & 0.27 \\
\hline 15 & 3.0 & 199.17 & 0.4 & 0.22 & 1.0 & 0.00 & 1.0 & 0.00 \\
\hline \begin{tabular}{|l|} 
Consoles Avg. \\
\end{tabular} & 2.2 & 209.07 & 2.2 & 5.06 & 1.0 & 0.10 & 1.0 & 0.10 \\
\hline 21 & 2.7 & 42.62 & 12.6 & 3.96 & 1.3 & 0.08 & 1.1 & 0.10 \\
\hline 22 & 1.1 & 35.13 & 11.5 & 11.07 & 1.2 & 0.19 & 1.2 & 0.19 \\
\hline 23 & 2.0 & 47.28 & 1.3 & 3.66 & 1.0 & 0.08 & 1.0 & 0.08 \\
\hline 24 & 1.8 & 44.39 & 5.4 & 1.29 & 1.1 & 0.02 & 1.1 & 0.02 \\
\hline 25 & 2.7 & 55.06 & 15.5 & 13.67 & 1.3 & 0.28 & 1.3 & 0.29 \\
\hline 26 & 3.2 & 39.05 & 11.6 & 3.96 & 1.3 & 0.11 & 1.2 & 0.08 \\
\hline Games Avg. & 2.3 & 44.64 & 9.6 & 8.88 & 1.2 & 0.19 & 1.2 & 0.18 \\
\hline & & & & & & & & \\
\hline 31 & 3.4 & 17.50 & 10.6 & 7.45 & 1.2 & 0.17 & 1.1 & 0.16 \\
\hline 32 & 3.2 & 17.18 & 14.4 & 12.09 & 1.3 & 0.29 & 1.2 & 0.29 \\
\hline 33 & 2.7 & 19.21 & 11.6 & 7.54 & 1.3 & 0.18 & 1.1 & 0.05 \\
\hline 34 & 4.0 & 15.85 & 17.7 & 7.42 & 1.5 & 0.20 & 1.3 & 0.21 \\
\hline 35 & 3.3 & 18.38 & 11.6 & 7.19 & 1.3 & 0.17 & 1.1 & 0.15 \\
\hline CDs Avg. & 3.3 & 17.59 & 13.3 & 8.85 & 1.3 & 0.22 & 1.2 & 0.21 \\
\hline 41 & 3.6 & 419.49 & 5.6 & 3.24 & 1.1 & 0.11 & 1.0 & 0.02 \\
\hline 42 & 4.1 & 482.24 & 5.0 & 0.99 & 1.1 & 0.04 & 1.0 & 0.02 \\
\hline 43 & 3.0 & 249.49 & 13.1 & 11.07 & 1.3 & 0.32 & 1.1 & 0.05 \\
\hline 44 & 2.9 & 418.81 & 7.5 & 3.76 & 1.1 & 0.06 & 1.1 & 0.07 \\
\hline 45 & 1.1 & 149.91 & 5.9 & 0.00 & 1.1 & 0.00 & 1.1 & 0.00 \\
\hline PDAs Avg. & 2.9 & 350.72 & 7.2 & 5.71 & 1.2 & 0.16 & 1.1 & 0.05 \\
\hline 51 & 2.0 & 475.30 & 9.0 & 2.71 & 1.2 & 0.06 & 1.1 & 0.05 \\
\hline 52 & 6.9 & 535.05 & 10.1 & 3.02 & 1.3 & 0.14 & 1.1 & 0.10 \\
\hline 53 & 3.9 & 589.54 & 5.2 & 1.43 & 1.1 & 0.05 & 1.0 & 0.03 \\
\hline 54 & 3.3 & 242.49 & 10.7 & 4.80 & 1.3 & 0.13 & 1.1 & 0.08 \\
\hline 55 & 3.0 & 1017.68 & 7.2 & 4.22 & 1.2 & 0.12 & 1.1 & 0.10 \\
\hline Printers Avg. & 3.9 & 560.66 & 8.6 & 3.93 & 1.2 & 0.14 & 1.1 & 0.08 \\
\hline & & & & & & & & \\
\hline 61 & 2.7 & 377.55 & 6.4 & 1.29 & 1.1 & 0.01 & 1.1 & 0.04 \\
\hline 62 & 1.0 & 125.61 & & & & & & \\
\hline 63 & 1.3 & 273.90 & 5.4 & 2.16 & 1.1 & 0.06 & 1.1 & 0.02 \\
\hline 64 & 2.0 & 833.45 & 2.9 & & 1.0 & & 1.0 & \\
\hline 65 & 1.9 & 199.30 & 6.3 & 1.62 & 1.1 & 0.00 & 1.1 & 0.03 \\
\hline Scanners Avg. & 1.7 & 264.60 & 6.0 & 1.66 & 1.1 & 0.03 & 1.1 & 0.03 \\
\hline $\begin{array}{c}\text { Overall } \\
\text { Averages }\end{array}$ & 2.9 & 239.04 & 8.7 & 7.57 & 1.2 & 0.19 & 1.1 & 0.15 \\
\hline
\end{tabular}


Appendix Table A2 (contd)

\begin{tabular}{|c|c|c|c|c|c|c|c|c|}
\hline \multicolumn{9}{|c|}{ e) Sweden } \\
\hline \multirow[t]{2}{*}{ Product } & \multirow{2}{*}{$\begin{array}{c}\text { Mean no. } \\
\text { of firms }\end{array}$} & \multirow{2}{*}{$\begin{array}{l}\text { Mean } \\
\text { Price }\end{array}$} & \multicolumn{2}{|c|}{ Coeff. of Variation } & \multicolumn{2}{|c|}{ Range Ratio } & \multicolumn{2}{|c|}{ Gap Ratio } \\
\hline & & & Mean & S.D. & Mean & S.D. & Mean & S.D. \\
\hline 11 & 2.5 & 396.82 & 6.4 & 5.16 & 1.1 & 0.11 & 1.1 & 0.05 \\
\hline 12 & 2.3 & 144.60 & 12.5 & 3.36 & 1.2 & 0.08 & 1.2 & 0.08 \\
\hline 13 & 1.0 & 148.65 & & & & & & \\
\hline 14 & 4.0 & 430.88 & 11.0 & 11.67 & 1.3 & 0.29 & 1.1 & 0.17 \\
\hline 15 & 4.8 & 268.80 & 1.4 & 0.77 & 1.0 & 0.02 & 1.0 & 0.02 \\
\hline Consoles Avg. & 2.6 & 298.52 & 8.4 & 7.30 & 1.2 & 0.17 & 1.1 & 0.11 \\
\hline & & & & & & & & \\
\hline 21 & 4.9 & 53.85 & 5.2 & 1.46 & 1.1 & 0.05 & 1.0 & 0.04 \\
\hline 22 & 5.4 & 29.45 & 28.0 & 14.79 & 2.3 & 1.01 & 1.5 & 0.75 \\
\hline 23 & 5.5 & 44.36 & 16.7 & 9.85 & 1.6 & 0.53 & 1.1 & 0.11 \\
\hline 24 & 2.4 & 43.96 & 6.4 & 4.85 & 1.1 & 0.11 & 1.1 & 0.08 \\
\hline 25 & 5.7 & 54.96 & 15.3 & 11.17 & 1.5 & 0.40 & 1.1 & 0.23 \\
\hline 26 & 4.3 & 46.58 & 6.8 & 1.21 & 1.2 & 0.04 & 1.0 & 0.05 \\
\hline Games Avg. & 4.7 & 45.53 & 13.6 & 12.18 & 1.5 & 0.67 & 1.2 & 0.38 \\
\hline & & 1648 & 127 & 525 & & 017 & 11 & 012 \\
\hline$\frac{31}{32}$ & $\frac{3.0}{4.9}$ & $\frac{10.40}{16.44}$ & $\frac{12.1}{12.4}$ & $\begin{array}{l}5.25 \\
3.23\end{array}$ & $\frac{1.5}{1.4}$ & 0.17 & $\frac{1.1}{1.1}$ & 0.12 \\
\hline 33 & 4.7 & 16.22 & 16.3 & 6.11 & 1.5 & 0.20 & 1.2 & 0.19 \\
\hline 34 & 4.2 & 17.75 & 12.3 & 6.76 & 1.3 & 0.20 & 1.1 & 0.15 \\
\hline 35 & 4.1 & 18.53 & 16.0 & 10.34 & 1.5 & 0.53 & 1.1 & 0.24 \\
\hline CDs Avg. & 4.6 & 17.10 & 14.0 & 6.93 & 1.4 & 0.29 & 1.1 & 0.17 \\
\hline 41 & 5.3 & 402.29 & 4.3 & 1.58 & 1.1 & 0.05 & 1.0 & 0.02 \\
\hline 42 & 8.2 & 578.38 & 6.1 & 1.45 & 1.2 & 0.06 & 1.0 & 0.04 \\
\hline 43 & 2.9 & 281.17 & 7.5 & 2.73 & 1.2 & 0.05 & 1.0 & 0.07 \\
\hline 44 & 3.3 & 495.95 & 4.6 & 2.21 & 1.1 & 0.04 & 1.1 & 0.04 \\
\hline 45 & 2.2 & 131.16 & 18.8 & 8.90 & 1.4 & 0.18 & 1.3 & 0.20 \\
\hline PDAs Avg. & 4.7 & 407.97 & 6.6 & 4.91 & 1.2 & 0.10 & 1.1 & 0.09 \\
\hline & 2.7 & 42080 & 85 & 3.54 & 12 & 013 & 10 & 006 \\
\hline 52 & 5.9 & 531.59 & 8.1 & 4.73 & 1.3 & 0.17 & 1.1 & 0.04 \\
\hline 53 & 2.5 & 669.68 & 8.0 & 7.23 & 1.2 & 0.21 & 1.1 & 0.11 \\
\hline 54 & 3.0 & 226.55 & 5.2 & 3.26 & 1.1 & 0.10 & 1.0 & 0.03 \\
\hline 55 & 4.3 & 1138.89 & 6.3 & 2.10 & 1.2 & 0.08 & 1.1 & 0.05 \\
\hline Printers Avg. & 3.8 & 624.78 & 7.1 & 4.46 & 1.2 & 0.15 & 1.1 & 0.06 \\
\hline & & & & & & & & \\
\hline 61 & 1.7 & 496.46 & 19.6 & 7.67 & 1.4 & 0.13 & 1.3 & 0.18 \\
\hline 62 & 1.2 & 119.55 & & & & & & \\
\hline 63 & 6.6 & 283.83 & 6.8 & 1.89 & 1.2 & 0.08 & 1.0 & 0.03 \\
\hline 64 & 1.1 & 1060.46 & 13.3 & & 1.2 & & 1.2 & \\
\hline 65 & 3.5 & 208.71 & 6.5 & 2.38 & 1.2 & 0.12 & 1.1 & 0.02 \\
\hline Scanners Avg. & 3.8 & 391.06 & 8.0 & 5.06 & 1.2 & 0.12 & 1.1 & 0.10 \\
\hline $\begin{array}{c}\text { Overall } \\
\text { Averages }\end{array}$ & 4.2 & 267.39 & 10.4 & 8.57 & 1.3 & 0.40 & 1.1 & 0.22 \\
\hline
\end{tabular}


Appendix Table A2 (contd)

\begin{tabular}{|c|c|c|c|c|c|c|c|c|}
\hline \multicolumn{9}{|c|}{ f) UK } \\
\hline \multirow[t]{2}{*}{ Product } & \multirow{2}{*}{$\begin{array}{c}\text { Mean no. } \\
\text { of firms }\end{array}$} & \multirow{2}{*}{$\begin{array}{l}\text { Mean } \\
\text { Price }\end{array}$} & \multicolumn{2}{|c|}{ Coeff. of Variation } & \multicolumn{2}{|c|}{ Range Ratio } & \multicolumn{2}{|c|}{ Gap Ratio } \\
\hline & & & Mean & S.D. & Mean & S.D. & Mean & S.D. \\
\hline 11 & 4.5 & 316.96 & 1.8 & 2.74 & 1.0 & 0.07 & 1.0 & 0.01 \\
\hline 12 & 5.8 & 119.58 & 5.1 & 4.02 & 1.1 & 0.10 & 1.0 & 0.04 \\
\hline 13 & 1.5 & 141.66 & 1.2 & 0.89 & 1.0 & 0.01 & 1.0 & 0.01 \\
\hline 14 & 3.0 & 438.32 & 4.2 & 6.80 & 1.1 & 0.17 & 1.0 & 0.11 \\
\hline 15 & 4.5 & 207.50 & 3.7 & 6.24 & 1.1 & 0.14 & 1.0 & 0.01 \\
\hline Consoles Avg. & 4.2 & 257.31 & 3.5 & 4.57 & 1.1 & 0.12 & 1.0 & 0.06 \\
\hline & & & & & & & & \\
\hline 21 & 5.3 & 47.93 & 6.8 & 2.00 & 1.2 & 0.06 & 1.0 & 0.03 \\
\hline 22 & 3.5 & 34.74 & 25.0 & 13.19 & 1.8 & 0.49 & 1.5 & 0.46 \\
\hline 23 & 3.7 & 50.92 & 13.9 & 6.54 & 1.3 & 0.22 & 1.1 & 0.17 \\
\hline 24 & 3.9 & 40.90 & 7.9 & 2.00 & 1.2 & 0.05 & 1.1 & 0.05 \\
\hline 25 & 4.9 & 54.88 & 16.3 & 14.74 & 1.5 & 0.55 & 1.2 & 0.30 \\
\hline 26 & 3.2 & 45.28 & 6.2 & 3.34 & 1.1 & 0.07 & 1.1 & 0.05 \\
\hline Games Avg. & 4.1 & 45.85 & 12.8 & 10.87 & 1.4 & 0.39 & 1.1 & 0.28 \\
\hline & & & & & & & & \\
\hline 31 & 7.9 & 17.52 & 17.5 & 3.42 & 1.6 & 0.17 & 1.0 & 0.06 \\
\hline 32 & 6.7 & 16.52 & 16.5 & 5.16 & 1.6 & 0.36 & 1.1 & 0.18 \\
\hline 33 & 6.3 & 17.17 & 15.9 & 7.78 & 1.5 & 0.36 & 1.1 & 0.06 \\
\hline 34 & 7.6 & 16.70 & 14.4 & 3.35 & 1.5 & 0.15 & 1.0 & 0.06 \\
\hline 35 & 5.5 & 18.19 & 16.3 & 2.12 & 1.5 & 0.07 & 1.1 & 0.12 \\
\hline CDs Avg. & 6.8 & 17.22 & 16.2 & 4.84 & 1.5 & 0.25 & 1.1 & 0.11 \\
\hline 41 & 5.9 & 376.94 & 3.9 & 4.47 & 1.1 & 0.14 & 1.0 & 0.01 \\
\hline 42 & 4.8 & 509.39 & 5.3 & 1.80 & 1.1 & 0.04 & 1.0 & 0.00 \\
\hline 43 & 2.3 & 247.30 & 7.5 & 4.03 & 1.2 & 0.15 & 1.1 & 0.09 \\
\hline 44 & 3.5 & 496.66 & 2.4 & 2.04 & 1.1 & 0.05 & 1.0 & 0.01 \\
\hline 45 & 1.3 & 132.29 & 14.7 & 12.63 & 1.3 & 0.23 & 1.3 & 0.23 \\
\hline PDAs Avg. & 3.7 & 359.66 & 5.2 & 5.27 & 1.1 & 0.12 & 1.0 & 0.09 \\
\hline 51 & 2.1 & 440.88 & 15.4 & 6.98 & 1.4 & 0.28 & 1.2 & 0.13 \\
\hline 52 & 4.9 & 519.66 & 8.4 & 3.89 & 1.2 & 0.12 & 1.1 & 0.09 \\
\hline 53 & 2.8 & 604.21 & 9.9 & 2.89 & 1.2 & 0.08 & 1.0 & 0.02 \\
\hline 54 & 4.1 & 247.01 & 13.4 & 6.12 & 1.3 & 0.16 & 1.1 & 0.07 \\
\hline 55 & 4.2 & 1013.79 & 3.7 & 2.63 & 1.1 & 0.06 & 1.0 & 0.03 \\
\hline Printers Avg. & 3.9 & 573.03 & 9.4 & 6.23 & 1.2 & 0.18 & 1.1 & 0.10 \\
\hline & & & & & & & & \\
\hline 61 & 2.0 & 429.41 & 0.4 & & 1.0 & & 1.0 & \\
\hline 62 & & & & & & & & \\
\hline 63 & 1.7 & 278.40 & 3.1 & 1.75 & 1.0 & 0.03 & 1.0 & 0.03 \\
\hline 64 & 2.3 & 1210.74 & 4.5 & 7.19 & 1.1 & 0.13 & 1.1 & 0.14 \\
\hline 65 & 1.0 & 206.65 & & & & & & \\
\hline Scanners Avg. & 2.0 & 830.65 & 3.9 & 5.92 & 1.1 & 0.11 & 1.1 & 0.11 \\
\hline $\begin{array}{c}\text { Overall } \\
\text { Averages }\end{array}$ & 4.4 & 271.52 & 10.0 & 8.52 & 1.3 & 0.31 & 1.1 & 0.17 \\
\hline
\end{tabular}


Appendix Table A2 (contd)

\begin{tabular}{|c|c|c|c|c|c|c|c|c|}
\hline \multicolumn{9}{|c|}{ g) Denmark } \\
\hline \multirow{2}{*}{ Product } & \multirow{2}{*}{$\begin{array}{c}\text { Mean no. } \\
\text { of firms }\end{array}$} & \multirow{2}{*}{$\begin{array}{l}\text { Mean } \\
\text { Price }\end{array}$} & \multicolumn{2}{|c|}{ Coeff. of Variation } & \multicolumn{2}{|c|}{ Range Ratio } & \multicolumn{2}{|c|}{ Gap Ratio } \\
\hline & & & Mean & S.D. & Mean & S.D. & Mean & S.D. \\
\hline 11 & 2.2 & 357.15 & 13.2 & 3.28 & 1.3 & 0.11 & 1.1 & 0.08 \\
\hline 12 & 1.9 & 133.65 & 8.7 & 4.40 & 1.1 & 0.07 & 1.1 & 0.08 \\
\hline 13 & 1.1 & 276.04 & 21.0 & & 1.3 & & 1.4 & \\
\hline 14 & 1.4 & 420.51 & 2.7 & 1.86 & 1.0 & 0.03 & 1.0 & 0.03 \\
\hline 15 & 1.0 & 270.56 & & & & & & \\
\hline \begin{tabular}{|l|} 
Consoles Avg. \\
\end{tabular} & 1.8 & 273.58 & 9.7 & 5.19 & 1.2 & 0.13 & 1.1 & 0.09 \\
\hline 21 & 2.2 & 53.01 & 15.9 & 3.17 & 1.3 & 0.05 & 1.2 & 0.14 \\
\hline 22 & 4.6 & 25.57 & 42.5 & 13.94 & 3.1 & 1.06 & 1.8 & 0.49 \\
\hline 23 & 4.4 & 48.20 & 14.5 & 10.61 & 1.4 & 0.30 & 1.2 & 0.24 \\
\hline 24 & 1.9 & 44.72 & 13.2 & 11.66 & 1.2 & 0.23 & 1.2 & 0.23 \\
\hline 25 & 5.1 & 60.55 & 18.2 & 12.27 & 1.6 & 0.38 & 1.2 & 0.23 \\
\hline 26 & 5.2 & 49.01 & 10.4 & 3.34 & 1.3 & 0.16 & 1.1 & 0.12 \\
\hline Games Avg. & 4.1 & 46.13 & 20.2 & 15.68 & 1.7 & 0.88 & 1.3 & 0.39 \\
\hline 31 & 2.4 & 18.71 & 11.3 & 7.11 & 1.2 & 0.24 & 1.1 & 0.18 \\
\hline 32 & 2.6 & 17.96 & 8.2 & 4.62 & 1.2 & 0.09 & 1.1 & 0.09 \\
\hline 33 & 2.1 & 18.23 & 6.8 & 4.18 & 1.1 & 0.07 & 1.1 & 0.07 \\
\hline 34 & 2.1 & 18.62 & 8.5 & 3.36 & 1.1 & 0.05 & 1.1 & 0.06 \\
\hline 35 & 2.7 & 19.96 & 8.8 & 10.49 & 1.2 & 0.32 & 1.1 & 0.04 \\
\hline CDs Avg. & 2.4 & 18.68 & 8.7 & 6.51 & 1.2 & 0.19 & 1.1 & 0.10 \\
\hline 41 & 3.9 & 379.45 & 6.0 & 3.30 & 1.2 & 0.11 & 1.0 & 0.03 \\
\hline 42 & 5.1 & 537.38 & 5.7 & 2.05 & 1.2 & 0.07 & 1.0 & 0.03 \\
\hline 43 & 2.0 & 299.22 & 5.1 & 3.85 & 1.1 & 0.08 & 1.0 & 0.06 \\
\hline 44 & 4.3 & 520.84 & 9.5 & 2.19 & 1.2 & 0.05 & 1.1 & 0.06 \\
\hline 45 & 3.6 & 138.96 & 13.2 & 2.40 & 1.3 & 0.16 & 1.1 & 0.09 \\
\hline PDAs Avg. & 4.0 & 384.33 & 7.9 & 3.84 & 1.2 & 0.12 & 1.1 & 0.06 \\
\hline 51 & 1.7 & 411.63 & 3.3 & 3.48 & 1.1 & 0.08 & 1.0 & 0.05 \\
\hline 52 & 5.5 & 537.67 & 9.5 & 4.49 & 1.3 & 0.14 & 1.0 & 0.05 \\
\hline 53 & 3.6 & 485.88 & 10.0 & 6.12 & 1.2 & 0.17 & 1.0 & 0.03 \\
\hline 54 & 1.6 & 269.67 & 12.1 & 5.73 & 1.2 & 0.13 & 1.1 & 0.11 \\
\hline 55 & 6.1 & 1084.28 & 10.7 & 4.21 & 1.3 & 0.13 & 1.0 & 0.02 \\
\hline Printers Avg. & 3.8 & 576.13 & 9.4 & 5.31 & 1.2 & 0.15 & 1.0 & 0.05 \\
\hline & & & & & & & & \\
\hline 61 & 1.6 & 406.35 & 5.3 & 3.87 & 1.1 & 0.06 & 1.1 & 0.06 \\
\hline 62 & 1.2 & 124.15 & 5.8 & 1.15 & 1.1 & 0.02 & 1.1 & 0.02 \\
\hline 63 & 2.6 & 303.49 & 7.7 & 10.58 & 1.2 & 0.30 & 1.0 & 0.02 \\
\hline 64 & 1.0 & 933.50 & & & & & & \\
\hline 65 & 1.9 & 226.58 & 6.0 & 1.59 & 1.1 & 0.07 & 1.1 & 0.02 \\
\hline Scanners Avg. & 1.6 & 371.22 & 6.3 & 6.06 & 1.1 & 0.17 & 1.1 & 0.04 \\
\hline $\begin{array}{c}\text { Overall } \\
\text { Averages }\end{array}$ & 3.1 & 262.85 & 11.6 & 10.51 & 1.3 & 0.52 & 1.1 & 0.23 \\
\hline
\end{tabular}


Appendix Table A2 (contd)

\section{h) International Averages}

\begin{tabular}{|c|c|c|c|c|c|c|c|c|}
\hline \multirow[t]{2}{*}{ Product } & \multirow{2}{*}{$\begin{array}{c}\text { Mean no. } \\
\text { of firms }\end{array}$} & \multirow{2}{*}{$\begin{array}{l}\text { Mean } \\
\text { Price }\end{array}$} & \multicolumn{2}{|c|}{ Coeff. of Variation } & \multicolumn{2}{|c|}{ Range Ratio } & \multicolumn{2}{|c|}{ Gap Ratio } \\
\hline & & & Mean & S.D. & Mean & S.D. & Mean & S.D. \\
\hline 11 & 3.1 & 334.07 & 5.7 & 7.44 & 1.1 & 0.19 & 1.0 & 0.07 \\
\hline 12 & 3.1 & 123.61 & 6.8 & 5.98 & 1.1 & 0.11 & 1.1 & 0.10 \\
\hline 13 & 1.9 & 166.12 & 6.6 & 10.37 & 1.1 & 0.19 & 1.1 & 0.18 \\
\hline 14 & 2.9 & 416.79 & 7.3 & 10.52 & 1.2 & 0.25 & 1.1 & 0.16 \\
\hline 15 & 2.8 & 224.06 & 1.4 & 2.68 & 1.0 & 0.06 & 1.0 & 0.02 \\
\hline Consoles Avg. & 2.9 & 244.58 & 6.1 & 7.67 & 1.1 & 0.17 & 1.1 & 0.11 \\
\hline & & & & & & & & \\
\hline 21 & 3.7 & 48.59 & 7.1 & 6.56 & 1.2 & 0.14 & 1.1 & 0.13 \\
\hline 22 & 3.3 & 35.09 & 27.4 & 18.16 & 2.1 & 1.02 & 1.5 & 0.58 \\
\hline 23 & 3.7 & 47.47 & 13.9 & 13.24 & 1.4 & 0.43 & 1.1 & 0.26 \\
\hline 24 & 3.2 & 43.63 & 8.4 & 11.14 & 1.2 & 0.54 & 1.1 & 0.23 \\
\hline 25 & 4.2 & 56.10 & 17.4 & 17.15 & 1.5 & 0.48 & 1.2 & 0.34 \\
\hline 26 & 3.9 & 48.17 & 10.1 & 10.17 & 1.2 & 0.23 & 1.1 & 0.25 \\
\hline Games Avg. & 3.7 & 46.76 & 13.9 & 14.90 & 1.4 & 0.62 & 1.2 & 0.35 \\
\hline 31 & 4.6 & 17.60 & 11.3 & 5.97 & 1.3 & 0.22 & 1.1 & 0.13 \\
\hline 32 & 4.6 & 17.00 & 14.6 & 8.38 & 1.5 & 0.35 & 1.1 & 0.17 \\
\hline 33 & 4.3 & 18.00 & 13.0 & 6.53 & 1.4 & 0.27 & 1.1 & 0.13 \\
\hline 34 & 4.1 & 17.00 & 12.0 & 6.59 & 1.3 & 0.25 & 1.1 & 0.19 \\
\hline 35 & 4.4 & 18.72 & 13.3 & 7.34 & 1.4 & 0.30 & 1.1 & 0.16 \\
\hline CDs Avg. & 4.4 & 17.66 & 12.8 & 7.08 & 1.4 & 0.29 & 1.1 & 0.16 \\
\hline 41 & 4.4 & 382.30 & 6.8 & 5.38 & 1.2 & 0.21 & 1.1 & 0.07 \\
\hline 42 & 6.1 & 512.72 & 5.6 & 2.38 & 1.2 & 0.10 & 1.1 & 0.08 \\
\hline 43 & 3.8 & 251.82 & 7.6 & 5.17 & 1.2 & 0.16 & 1.1 & 0.06 \\
\hline 44 & 3.9 & 455.46 & 5.4 & 3.39 & 1.1 & 0.09 & 1.1 & 0.06 \\
\hline 45 & 2.2 & 132.85 & 11.6 & 7.97 & 1.3 & 0.19 & 1.1 & 0.15 \\
\hline PDAs Avg. & 4.2 & 367.80 & 6.7 & 4.85 & 1.2 & 0.15 & 1.1 & 0.08 \\
\hline & & & & & & & & \\
\hline 51 & 2.6 & 412.52 & 11.7 & 9.18 & 1.3 & 0.26 & 1.2 & 0.19 \\
\hline 52 & 6.2 & 529.55 & 8.2 & 4.16 & 1.2 & 0.15 & 1.0 & 0.08 \\
\hline 53 & 3.5 & 598.11 & 8.3 & 5.38 & 1.2 & 0.13 & 1.1 & 0.09 \\
\hline 54 & 2.9 & 249.67 & 9.2 & 6.02 & 1.2 & 0.15 & 1.1 & 0.08 \\
\hline 55 & 4.0 & 1040.74 & 7.5 & 4.62 & 1.2 & 0.13 & 1.1 & 0.07 \\
\hline Printers Avg. & 4.0 & 582.03 & 8.7 & 5.91 & 1.2 & 0.17 & 1.1 & 0.11 \\
\hline 61 & 2.2 & 404.52 & 10.5 & 6.26 & 12 & 011 & 12 & 0.12 \\
\hline 62 & 2.5 & 110.07 & 10.0 & 5.26 & 1.3 & 0.17 & 1.1 & 0.09 \\
\hline 63 & 3.0 & 278.61 & 7.3 & 6.76 & 1.2 & 0.16 & 1.1 & 0.12 \\
\hline 64 & 1.6 & 1104.59 & 5.7 & 6.72 & 1.1 & 0.12 & 1.1 & 0.12 \\
\hline 65 & 2.4 & 214.80 & 10.1 & 10.40 & 1.2 & 0.26 & 1.1 & 0.22 \\
\hline Scanners Avg. & 2.4 & 385.92 & 8.9 & 7.50 & 1.2 & 0.18 & 1.1 & 0.15 \\
\hline $\begin{array}{c}\text { Overall } \\
\text { Averages }\end{array}$ & 3.8 & 256.19 & 10.1 & 9.47 & 1.3 & 0.36 & 1.1 & 0.20 \\
\hline
\end{tabular}



Figure 1: Screenshot from price listing service Kelkoo (UK Site)

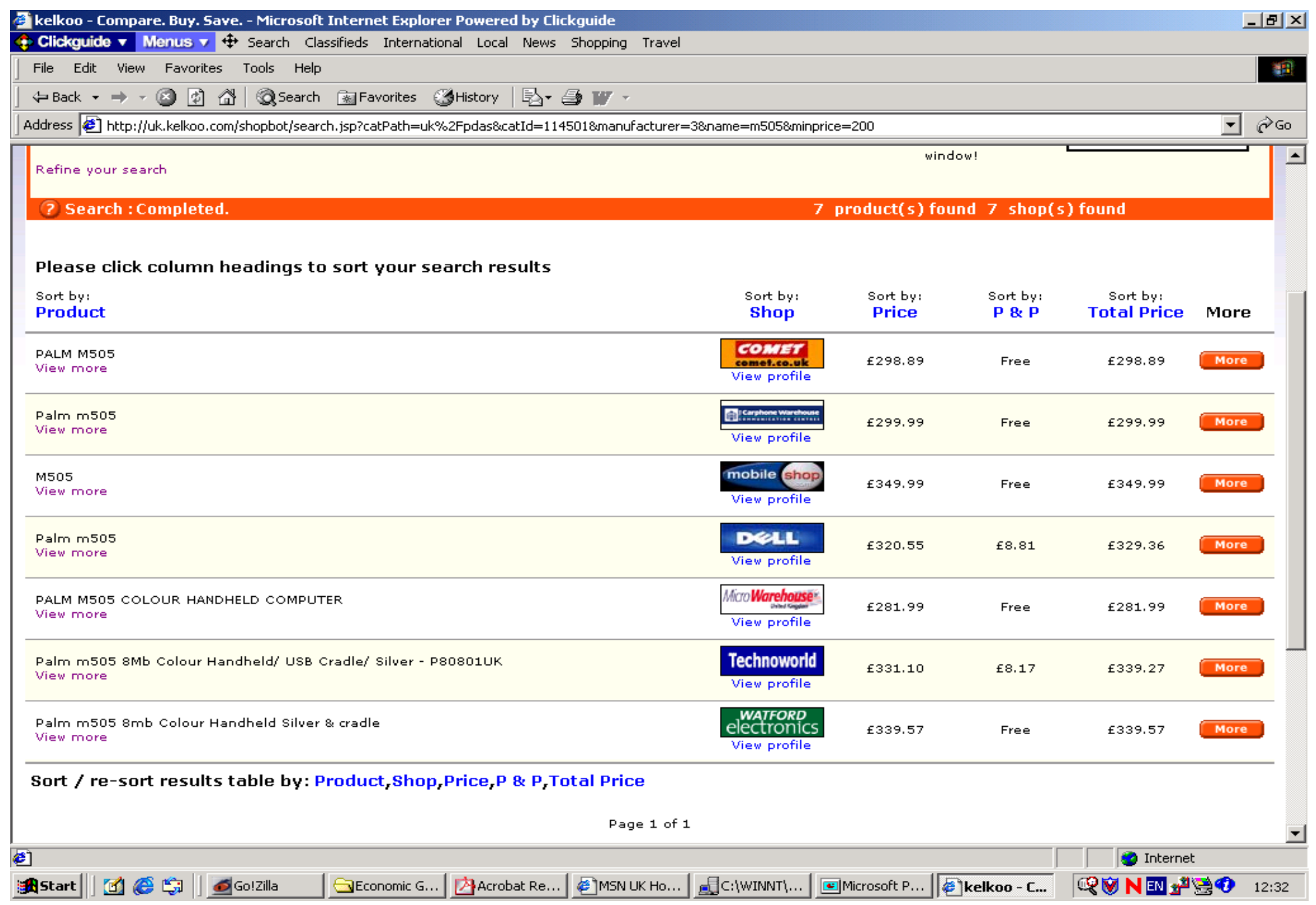


Figure 2: Price Dispersion against Number of Firms listing prices

$\multimap \mathrm{CoV} \triangle \mathrm{Gap}-\square \quad$ Range

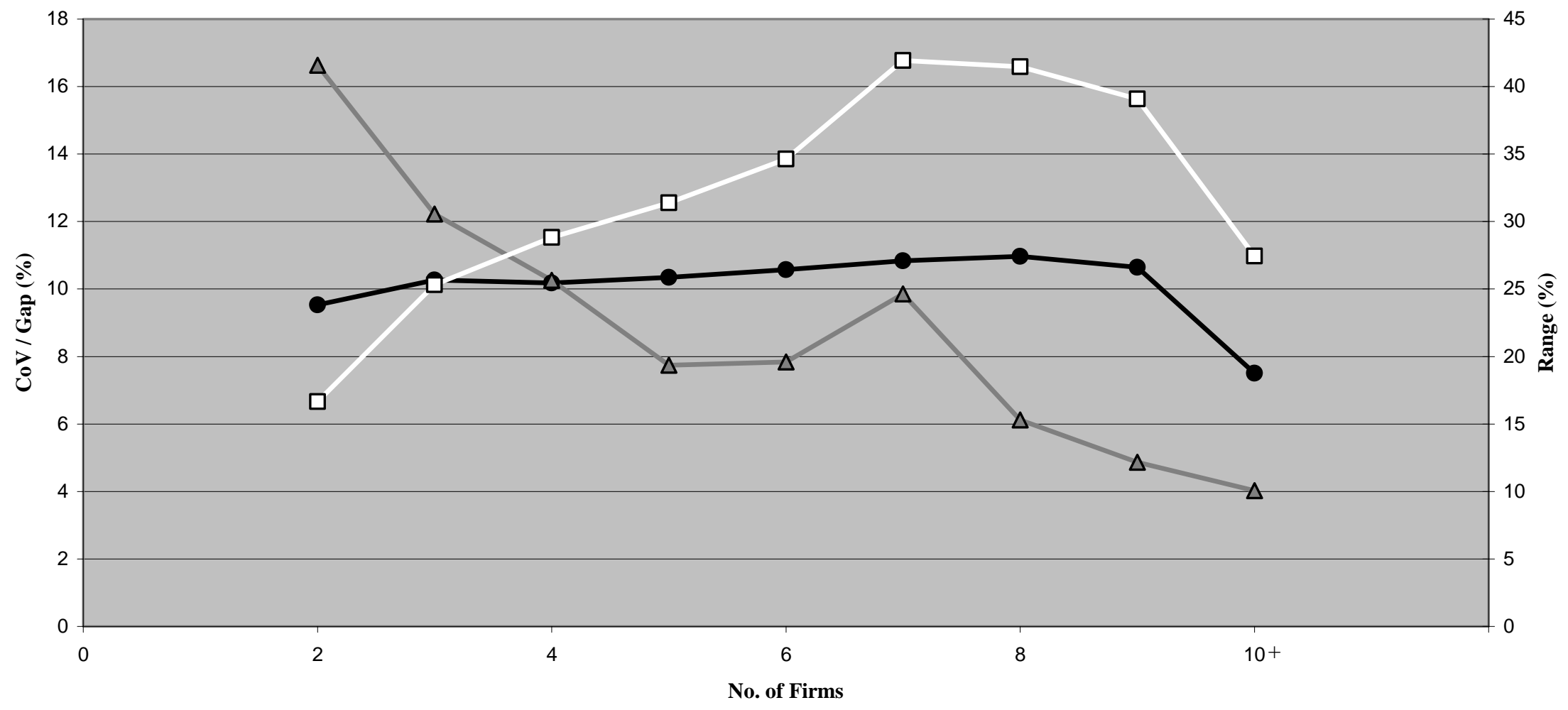


Figure 3: Price Dispersion Measures over Time

$$
\multimap \mathrm{CoV} \triangle \mathrm{Gap}-\square \quad \text { Range }
$$

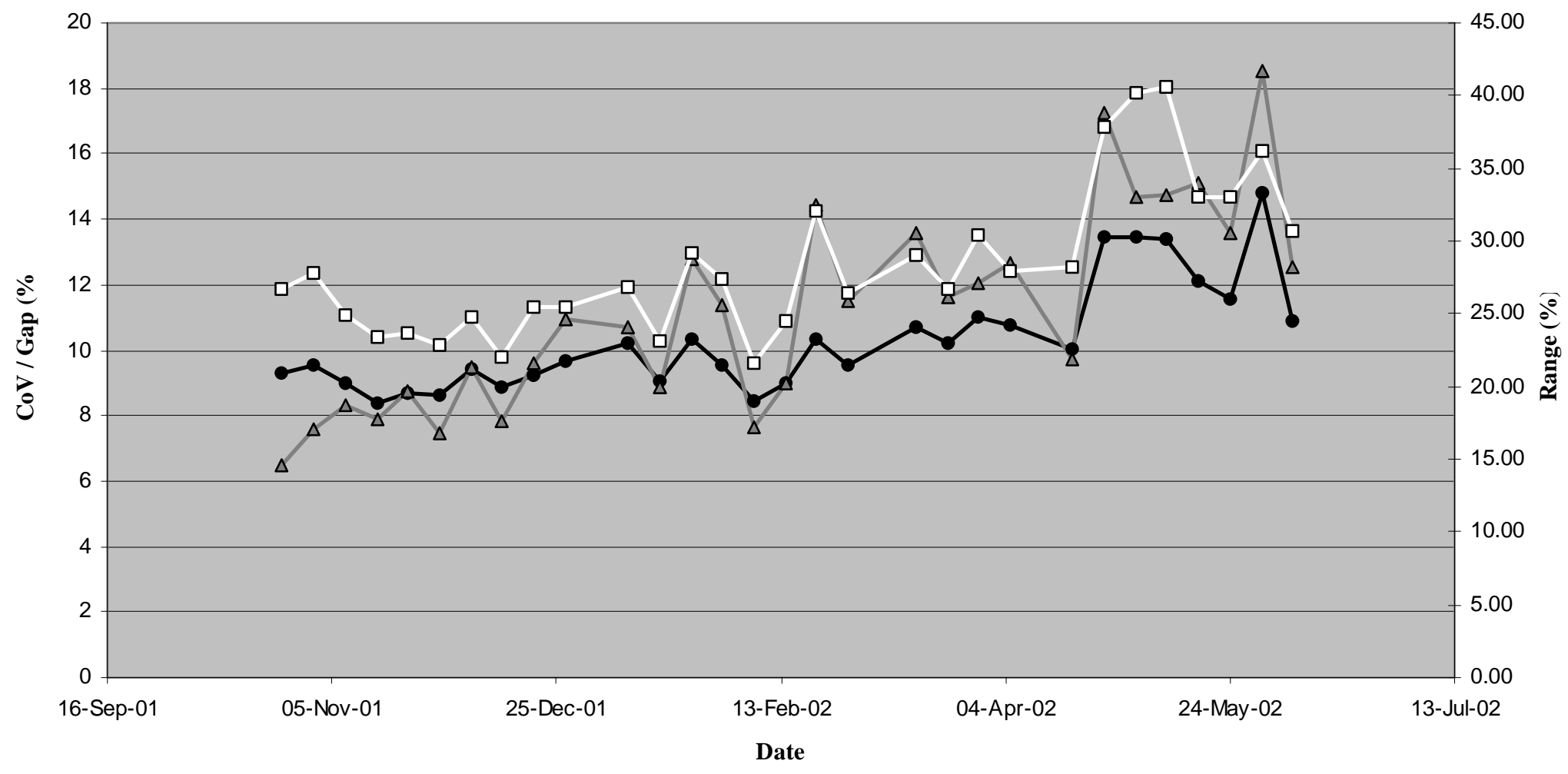


Figure 4: Average Number of Firms listing prices over Time

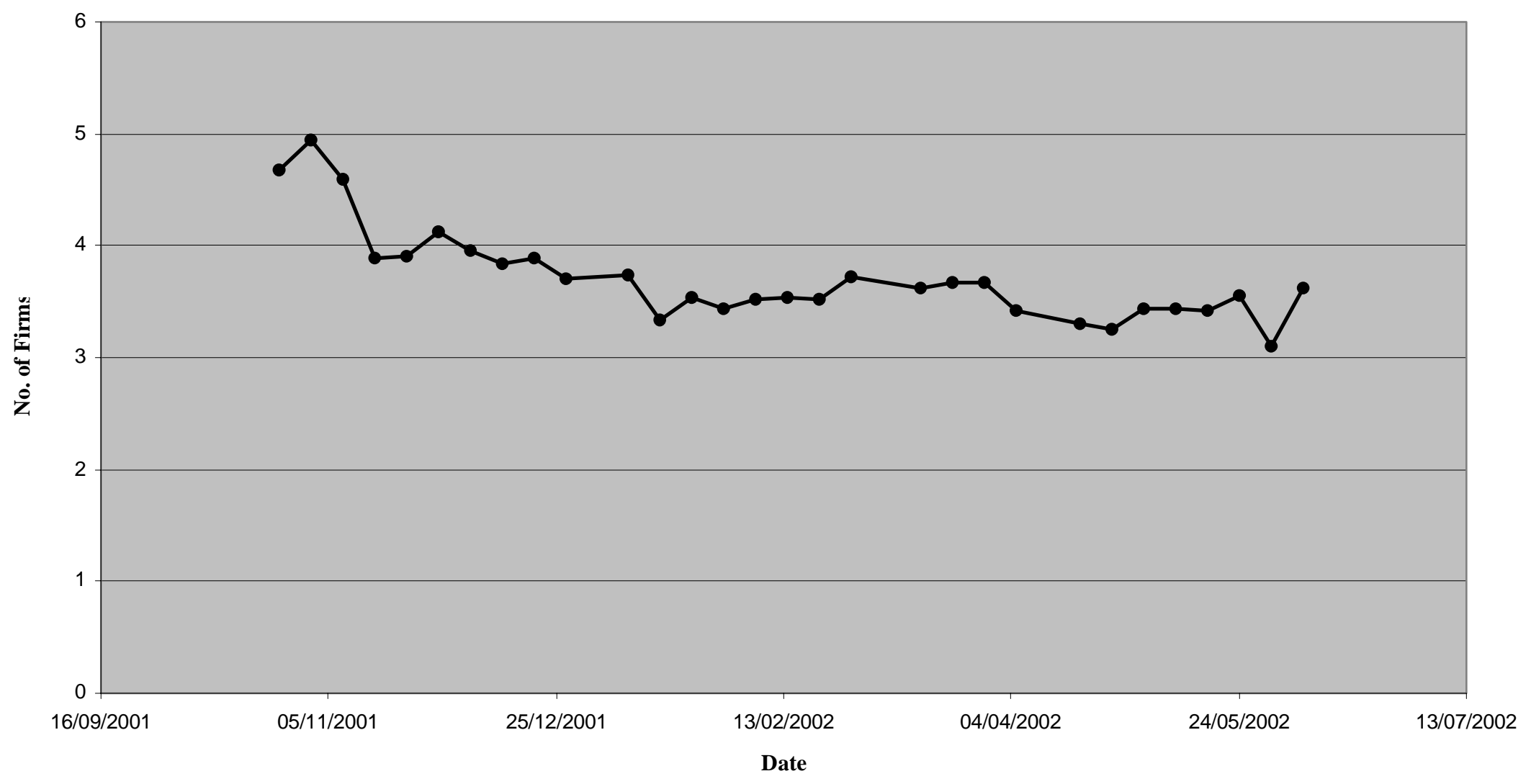


Figure 5: Coefficient of Variation against Mean Price

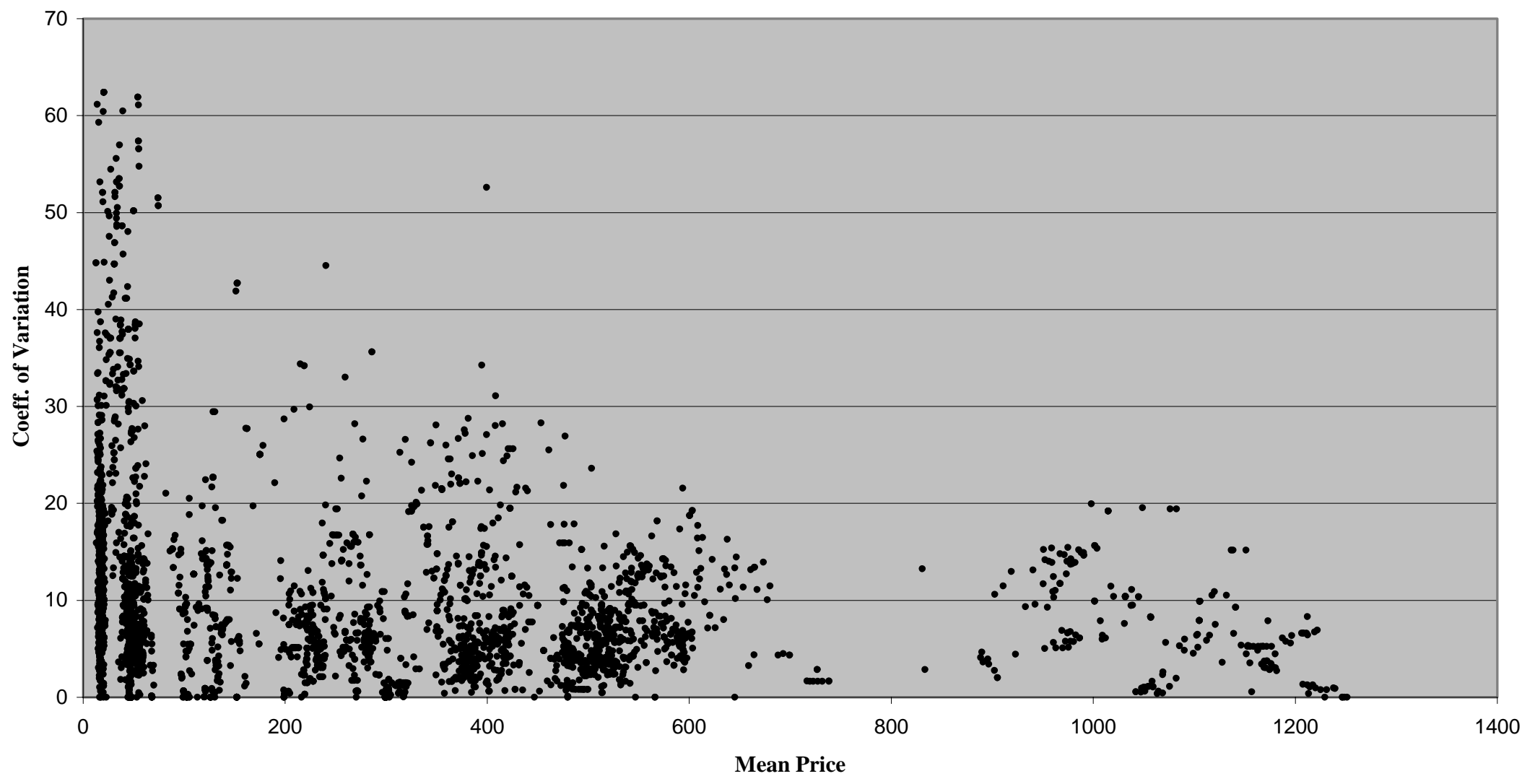


Figure 6: Range against Minimum Price

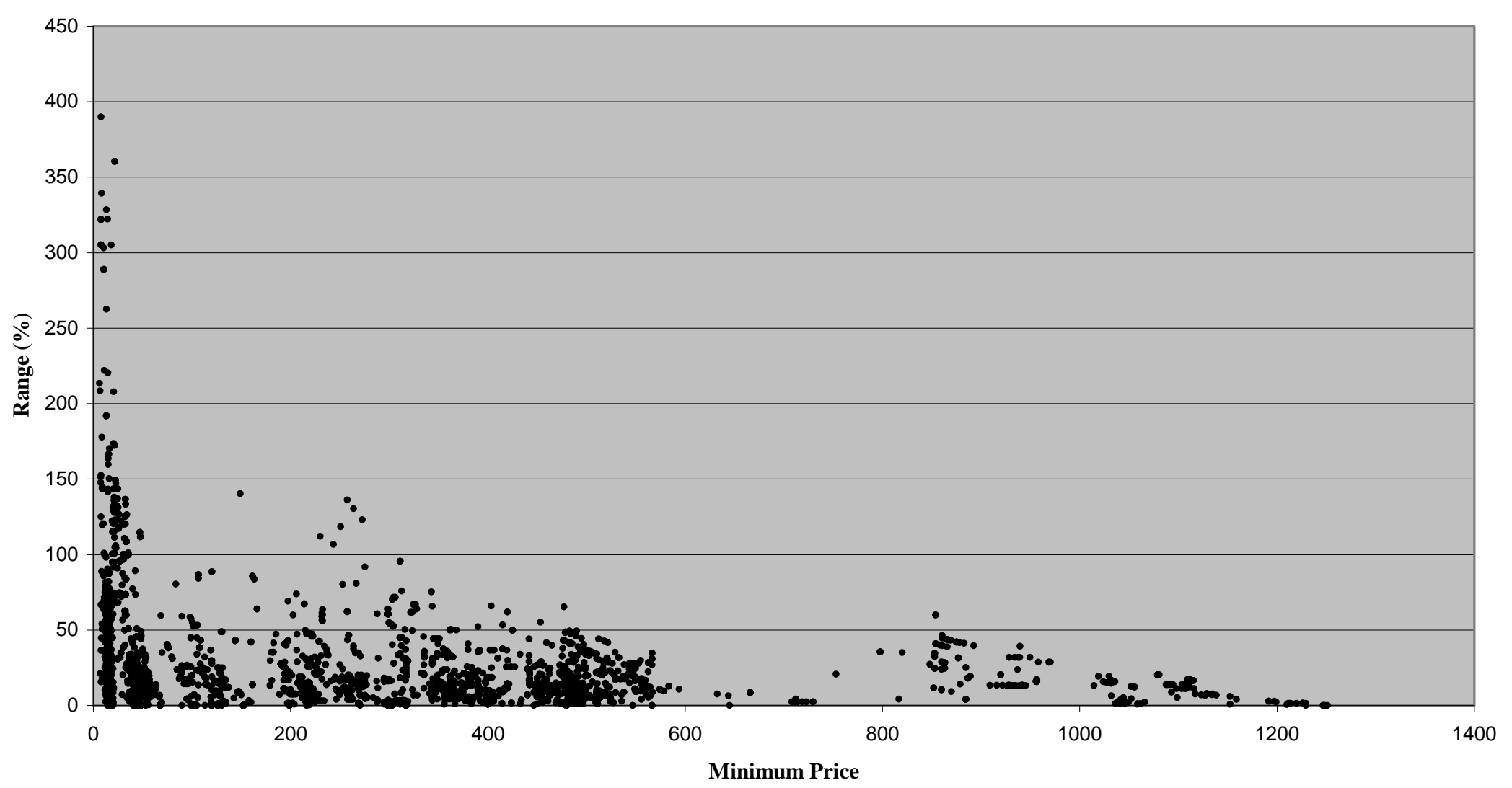


Figure 7: Gap against Minimum Price

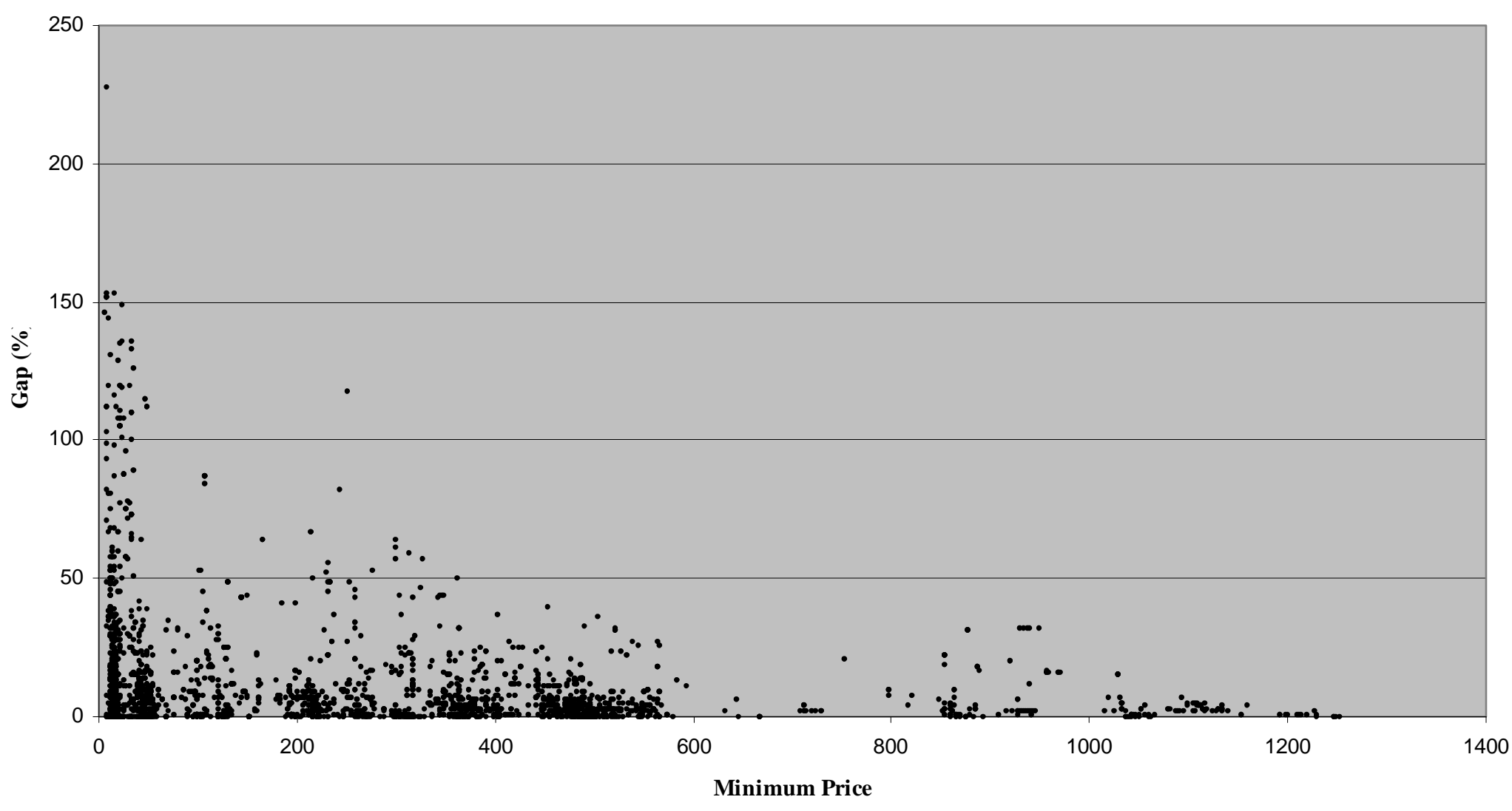

